\title{
Effect of Chitosan, Putrescine and Irrigation Levels on the Drought Tolerance of Sour Orange Seedlings
}

\author{
Shaimaa A. Mohamed, H. S. Ahmed and Amal A. El-Baowab \\ Citriculture Department, Horticulture Institute, Agricultural Research Centre, Cairo, \\ Egypt.
}

\begin{abstract}
A STUDY was conducted on one- year old sour orange seedlings in long term experiment during 2014 and 2015, held in greenhouse of EL-Maamora station, Horticulture Research Institute. The aim of trial was to evaluate foliar chitosan or putrescine application at 0,50 , $100,150 \mathrm{ppm}$ and three levels of irrigation (7, 14 and 21 days) contributing to three levels of drought stress (zero, moderate and severe, respectively) on growth, leaf biochemical attributes and antioxidant enzymes activity. Results showed that most of the vegetative growth indices, plant height $\%$, stem diameter $\%$, leaves number, area, fresh and dry weight and relative water content(RWC) \%,leaf carbohydrates and protein \% were significantly decreased with increasing drought level and that chitosan and putrescine application resulted in enhancement gradually of the previous parameters by increasing concentrations applied. Putrescine was more effective at 50 and $100 \mathrm{ppm}$ compared to $150 \mathrm{ppm}$, whereas chitosan was more effective at 100 and $150 \mathrm{ppm}$ than $50 \mathrm{ppm}$.
\end{abstract}

Keyword: Sour orange, Chitosan (cht), Putrescine (put), Foliar sprays, Water deficit, Antioxidant enzymes, Phenols, Proline.

\section{Introduction}

Egypt is suffering from water poverty as water deficit is more than one-third of the amount of available water. According to Anon (2015), the agriculture sector remains the biggest utilize of water in Egypt as it acquired 62.15 billion cubic meters in 2015 and accounts for $81.5 \%$ of the total water consumption. Thus limiting amount of water use in Agriculture is put gradually in consideration. Therefore, regarding fruit production, several attentions are made for investigating the growth of fruit trees under limited levels of irrigation water. Water deficient is most prevalent environmental factor limiting crop productivity, and the global climate change is increasing the frequency of severe drought conditions, thereby it adversely affects morphological and physiological characteristics as well as biochemical contents of plants Basu et al (2016). The most important part of fruit trees that response to irrigation conditions is the rootstock. Sour orange (Citrus aurantium L.) has been and probably continues to be the most common and widespread rootstock in Egypt. It resists gum and rotting roots diseases, tolerates low temperatures and it is compatible with most citrus species in all growth attributes affecting tree yield and fruit quality Castle et al. (1992). The effect of sour orange rootstock on the growth and productivity of several citrus species is already reported Castle (1995). However, its growth under deficit amount of irrigation water might affect it growth and its influence on the scion above. Several researchers studied the growth and productivity of the sour orange rootstock under water deficient conditions Levy (1998),Cimen and Yesiloglu (2016), Robles et al.(2017)and they all stated the declining of growth and the productivity of both rootstock and scion above. Thoughts had been made to encourage plant growth under water deficiency by foliar spraying with some agrochemicals working as anti- transparent or stress tolerant Farouk \& Ramadan (2012) and Malekpoor et al. (2016)

Chitosan (Chi) is an amino polysaccharide obtained by alkaline deacetylation of chitin extracted from the exoskeleton of crustaceans such as shrimps and crabs, or cell walls of some fungi Dzung et al. (2011). It has interesting characteristics such as biocompatibility, non-toxicity, low allergenicity and biodegradability that allows it to be used in various applications such as coating, preservative, antioxidant, antimicrobial and soil 
modifier Katiyar et al. (2015). In addition, foliar spraying of chitosan has been shown to stimulate vegetative growth and improve yield and quality of several fruit and vegetable crops Cheung et al. (2016) and Shehata et al. (2012).

In the meantime, putrescine (Put) is one of the polyamines that are considered growth substances. Putrescine participates in several processes of plant growth and development and its role as anti-senescence and anti-stress agent is previously reported Ahmed et al. (2017). It works as antioxidant and improves cell membrane stability $\mathrm{Li}$ et al. (2015). It plays role in modulating the defense response of plants to varied environmental stresses including drought stress Ahmed et al. (2013) and Khorshidi \& Hamedi (2014).

The objective of this research therefore, was to study the effect of chitosan and putrescine foliar sprayson thesour orange rootstock response grown under three levels of drought conditions.

\section{Materials and Methods}

Experimental site and plant materials

The experiment was conductedon one- year old Sour orange seedlings during the two growing seasons of 2014 and 2015. Seedlings were grown inthe greenhouse of EL-Maamoura experimental station of the Horticulture Research Institute in Alexandria. Seedlings were singly planted in polyethylene bags $(34 \times 17 \mathrm{~cm})$ filled with $4 \mathrm{~kg}$ soil containing sand, clay and degraded horse manure mixed at a ratio of $2: 1: 1$.

\section{Treatments and statistical design}

Ninety six seedlings were arranged in a splitsplit- plot design with 4 blocks. The study was represented by three irrigation levels, Irrigation every 7 days $\left(I_{1}\right)$, irrigation every 14 days $\left(I_{2}\right)$ and irrigation every 21 days $\left(\mathrm{I}_{3}\right)$ representing three levels of drought stress: zero, moderate and severe, respectively. The irrigation levels occupied the main plots, each of main plots was divided to two sub- plots which represented two foliar sprayed Agrochemicals (Agr.), chitosan (Cht) and putrescine (Put). Each sub-plots was divided to four sub- sub- plot that specified to the four concentration (C) used, 0 (water spray), 50, 100 and $150 \mathrm{ppm}$. All treatments and their interactions inside each block were distributed randomly. Seedlings were foliar sprayed at first June and July during 2014 and 2015. In late November the investigation was ended and the following measurements were recorded:

The investigation was ended in late November and the following measurements were recorded: Plant measurements

Vegetative growth

Plant height $(\mathrm{cm})$ and stem diameter $(\mathrm{cm})$ at
$20 \mathrm{~cm}$ above soil surface were measured at the beginning and end of the experimental season and the percentages of plant height and diameter were calculated as follow:

Plant height $\%=$ Final height - Initial height $\times 100$ Initial height

Stem diameter $\%=$ Final diameter - Initial diameter $\times 100$ Initial diameter

In addition, total number of leaves per seedling was counted, leaf fresh and dry weights $(\mathrm{g})$ were recorded and leaf area $\left(\mathrm{cm}^{2}\right)$ was estimated according to the method of Radwan (1973).

\section{Biochemical parameters}

Total leaf chlorophyll (SPAD units) was determined in fresh leaf samples composed of 10 leaves collected randomly from each seedling, using Minolita SPAD chlorophyll meter according to Yadava (1986). Also, leaf relative water content (RWC) was estimated by weighing (g) fresh leaves (FW) and then immersing it in water until the weight of leaves was constant, then water saturated leaves (SW) were weighed and dried for 72 hours at $70^{\circ} \mathrm{C}$ for dry weight (DW) determination and the percentage of leaf relative water content (RWC) was calculated as follows:

\section{RWC $\%=$ Fresh weight - Dry weight $\times 100$ Saturated weight - Dry weight}

Moreover, peroxidase in a sample of 5 leavesper replicate fresh weight. peroxidase (POX) activity (min/g FW) was measured according to the method of Barman (1947) and leaf catalase activity ( $\mu$ mole $\mathrm{H}_{2} \mathrm{O}_{2} \mathrm{FW} / \mathrm{min}$ ) was assayed as described by Kara and Mishra (1976).

Leaf protein content (\%) was determined in the extract of fresh leaf tissues according to Coomassie Brilliant Bule G250 method using bovine serum albumin as standard and measured at wave $595 \mathrm{~nm}$ length according to Bradford (1976). Total carbohydrates expressed as percent on dry weight basis were determined as described by Woodman (1941). Total phenolic compounds were estimated as g tannic acid/ $100 \mathrm{~g}$ dry weight using Folin- Denis reagent and measured at $750 \mathrm{~nm}$ as according to Weurman and Swain(1955). Moreover, proline content (mg/ g dry weight) was determined colorimetrically in the extract of dry leaf tissues by using ninhydrin reagent and measured at $520 \mathrm{~nm}$ according to Bates et al. (1973).

\section{Statistical analysis}

The variance of each individual factor and their interactions were compared by Duncan's Multiple Range Test at 5\% level according to 
Steel and Torrie, (1980). The statistical analysis was performed using MSTAT- C Package (1996).

\section{Results and Discussion}

Vegetative growth

It was clear that the vegetative growth indices including plant height, diameter, number of leaves per seedling, leaf area, leaf fresh and dry weights were respond differently to foliar spray applications (Tables 1, 2, 3 and 4), therefore the results showed that there was a significant superiority of putrescine (Put) spraying in fresh weight, \% (RWC\%) and dry weight during both years and 2015 only, respectively. Meanwhile, percentages of plant height growth or leaf area were more responsive to Cht spraying as compared to Put in 2014, beside the percentages of stem diameter growth did not affected markedly by foliar spray applications, also no regular trend of superiority of foliar spray application on number of leaves. Vegetative growth variables were affected significantly by the different irrigation levels and the different rates of chitosan and putrescine foliar sprays. The influence of the irrigation levels obtained in a descending order where the highest values appeared under irrigation every 7 days followed by 14 days and then the lowest values that was recorded for irrigation every 21 days. This was particularly evident in the percentages of plant height, number of leaves, leaf dry weight and relative water content, as the values declined compared to the control by (21.68 \& 22.30), (20.93 \& 18.79), (9.80 \& 8.37), (14.43 \&15.15) in 2014 and 2015, respectively. Similar trend was observed in percentage of stem diameter, leaf area, and fresh weight with insignificant differences between irrigation periods 14 and 21 days during first growing season. Conversely, the significant effect of doses used was obvious in the ascending order along increasing the doses applied.

The lowest values were obtained from the control-water spray $(0 \mathrm{ppm})$, followed by those treated with $50 \mathrm{ppm}$ then $100 \mathrm{ppm}$, whereas the highest values were observed at $150 \mathrm{ppm}$ that occurred in percentages of stem diameter in both years, number of leaves in 2014 and leaf area or $\mathrm{RWC} \%$ in 2015 . There were no detectable appreciable differences between 100 and 150 $\mathrm{ppm}$ in percentage of plant height increase, fresh and dry weights and $\mathrm{RWC} \%$ during first year and number of leaves in second year. Also, no significant variations between doses of 50 and 100 ppm in leaf area in 2014 only.

With regard to the efficacy of combinations between irrigation intervals and foliar spray applications for hampering the passive influence of drought stress on prosperity of vegetative growth which was appeared on growth measurements values, the current data elucidate that the combination of $\mathrm{Cht}$ and irrigation every 7 day resulted in statistical superiority in the percentages

TABLE 1. Main and interaction effect of chitosan and putrescine foliar sprays and different irrigation levels on plant height and stem diameter in 2014 and 2015

\begin{tabular}{|c|c|c|c|c|c|c|c|c|}
\hline \multicolumn{9}{|c|}{ Plant height (\%) } \\
\hline \multirow{3}{*}{$\begin{array}{c}\text { Agrochemicals } \\
\text { (Agr.) }\end{array}$} & \multicolumn{3}{|c|}{ Irrigation intervals (I) } & \multicolumn{5}{|c|}{ Concentration (C) } \\
\hline & \multirow[b]{2}{*}{$I_{1}$} & \multirow[b]{2}{*}{$\mathbf{I}_{2}$} & \multirow[b]{2}{*}{$\mathbf{I}_{3}$} & \multirow{2}{*}{$\begin{array}{c}0 \\
\mathrm{ppm}\end{array}$} & \multirow{2}{*}{$\begin{array}{c}\mathbf{5 0} \\
\text { ppm }\end{array}$} & \multirow{2}{*}{$\begin{array}{l}100 \\
\mathrm{ppm}\end{array}$} & \multirow{2}{*}{$\begin{array}{c}150 \\
\text { ppm }\end{array}$} & \multirow[t]{2}{*}{ Mean } \\
\hline & & & & & & & & \\
\hline & \multicolumn{8}{|c|}{2014} \\
\hline Cht & $26.64^{\mathrm{a}}$ & $20.38^{c}$ & $19.15^{\mathrm{d}}$ & $18.12^{\mathrm{f}}$ & $19.18^{\mathrm{e}}$ & $26.04^{\mathrm{a}}$ & $24.88^{\mathrm{b}}$ & $22.05^{\mathrm{a}}$ \\
\hline Put & $22.63^{\mathrm{b}}$ & $21.53^{\mathrm{b}}$ & $19.42^{\text {cd }}$ & $18.18^{\mathrm{f}}$ & $20.06^{\mathrm{d}}$ & $22.29^{c}$ & $24.26^{\mathrm{b}}$ & $21.20^{b}$ \\
\hline \multirow[t]{2}{*}{ Mean } & $24.63^{\mathrm{a}}$ & $20.96^{b}$ & $19.29^{c}$ & $18.15^{\mathrm{c}}$ & $19.62^{b}$ & $24.16^{\mathrm{a}}$ & $24.57^{\mathrm{a}}$ & \\
\hline & \multicolumn{8}{|c|}{2015} \\
\hline Cht & $25.73^{\mathrm{a}}$ & $21.32^{\mathrm{c}}$ & $18.67^{\mathrm{e}}$ & $17.34^{\mathrm{e}}$ & $19.30^{\mathrm{d}}$ & $26.95^{\mathrm{a}}$ & $24.03^{\mathrm{c}}$ & $21.91^{\mathrm{a}}$ \\
\hline Put & $24.23^{\mathrm{b}}$ & $20.36^{\mathrm{d}}$ & $20.16^{\mathrm{d}}$ & $17.38^{\mathrm{e}}$ & $19.67^{\mathrm{d}}$ & $23.82^{\mathrm{c}}$ & $25.46^{\mathrm{b}}$ & $21.58^{\mathrm{a}}$ \\
\hline Mean & $24.98^{\mathrm{a}}$ & $20.84^{b}$ & $19.41^{\mathrm{c}}$ & $17.36^{\mathrm{d}}$ & $19.48^{c}$ & $25.38^{\mathrm{a}}$ & $24.75^{b}$ & \\
\hline \multicolumn{9}{|c|}{ Stem diameter $(\%)$} \\
\hline & \multicolumn{8}{|c|}{2014} \\
\hline Cht & $27.12^{\mathrm{a}}$ & $23.25^{\mathrm{bc}}$ & $23.59^{\mathrm{bc}}$ & $21.54^{\mathrm{e}}$ & $23.27^{\mathrm{d}}$ & $25.97^{\mathrm{c}}$ & $27.84^{\mathrm{b}}$ & $24.65^{\mathrm{a}}$ \\
\hline Put & $27.94^{\mathrm{a}}$ & $23.93^{\mathrm{b}}$ & $22.93^{\mathrm{c}}$ & $21.57^{\mathrm{e}}$ & $23.91^{\mathrm{d}}$ & $25.17^{\mathrm{c}}$ & $29.10^{\mathrm{a}}$ & $24.94^{\mathrm{a}}$ \\
\hline \multirow[t]{2}{*}{ Mean } & $27.53^{\mathrm{a}}$ & $23.59^{b}$ & $23.26^{b}$ & $21.55^{\mathrm{d}}$ & $23.59^{c}$ & $25.57^{\mathrm{b}}$ & $28.47^{a}$ & \\
\hline & \multicolumn{8}{|c|}{2015} \\
\hline Cht & $29.75^{\mathrm{a}}$ & $28.44^{\mathrm{b}}$ & $24.14^{c}$ & $21.34^{\mathrm{e}}$ & $25.69^{\mathrm{e}}$ & $29.98^{c}$ & $32.75^{\mathrm{a}}$ & $27.44^{\mathrm{a}}$ \\
\hline Put & $28.73^{\mathrm{b}}$ & $28.75^{b}$ & $24.35^{\mathrm{c}}$ & $21.17^{\mathrm{f}}$ & $27.25^{\mathrm{d}}$ & $29.96^{c}$ & $30.74^{b}$ & $27.28^{\mathrm{a}}$ \\
\hline Mean & $29.24^{\mathrm{a}}$ & $28.60^{b}$ & $24.25^{c}$ & $21.26^{d}$ & $26.47^{\mathrm{c}}$ & $29.97^{b}$ & $37.74^{a}$ & \\
\hline
\end{tabular}


TABLE 2. Main and interaction effect of chitosan and putrescine foliar sprays and different irrigation Levels on Leaf number and leaf area

\begin{tabular}{|c|c|c|c|c|c|c|c|c|}
\hline \multicolumn{9}{|c|}{ Leaf number } \\
\hline \multirow{3}{*}{$\begin{array}{c}\text { Agrochemicals } \\
\text { (Agr.) }\end{array}$} & \multicolumn{3}{|c|}{ Irrigation levels } & \multicolumn{5}{|c|}{ Concentration } \\
\hline & \multirow[b]{2}{*}{$\mathbf{I}_{1}$} & \multirow[b]{2}{*}{$\mathbf{I}_{2}$} & \multirow[b]{2}{*}{$\mathbf{I}_{3}$} & \multirow{2}{*}{$\begin{array}{c}0 \\
\text { ppm }\end{array}$} & \multirow{2}{*}{$\begin{array}{c}\mathbf{5 0} \\
\text { ppm }\end{array}$} & \multirow{2}{*}{$\begin{array}{l}100 \\
\text { ppm }\end{array}$} & \multirow{2}{*}{$\begin{array}{c}150 \\
\text { ppm }\end{array}$} & \multirow[t]{2}{*}{ Mean } \\
\hline & & & & & & & & \\
\hline & \multicolumn{8}{|c|}{2014} \\
\hline Cht & $111.00^{\mathrm{b}}$ & $104.50^{c}$ & $90.00^{\mathrm{d}}$ & $85.00^{\mathrm{e}}$ & $92.33^{\mathrm{d}}$ & $107.67^{\mathrm{b}}$ & $122.33^{\mathrm{a}}$ & $101.83 b$ \\
\hline Put & $120.00^{\mathrm{a}}$ & $107.08 b^{c}$ & $92.67^{\mathrm{d}}$ & $84.44^{\mathrm{e}}$ & $100.00^{c}$ & $119.56^{\mathrm{a}}$ & $122.33^{\mathrm{a}}$ & $106.58^{\mathrm{a}}$ \\
\hline \multirow[t]{2}{*}{ Mean } & $115.50^{\mathrm{a}}$ & $105.79^{b}$ & $91.33^{\mathrm{c}}$ & $84.72^{\mathrm{d}}$ & $96.17^{\mathrm{c}}$ & $113.61^{\mathrm{b}}$ & $122.33^{\mathrm{a}}$ & \\
\hline & \multicolumn{8}{|c|}{2015} \\
\hline Cht & $196.33^{\mathrm{a}}$ & $173.75^{\mathrm{c}}$ & $160.00^{\mathrm{d}}$ & $145.33^{\mathrm{f}}$ & $169.11^{\mathrm{d}}$ & $201.33^{\mathrm{a}}$ & $191.00^{\mathrm{b}}$ & $176.70 \mathrm{a}$ \\
\hline Put & $180.17^{\mathrm{b}}$ & $163.67^{d}$ & $145.75^{\mathrm{e}}$ & $145.11^{\mathrm{f}}$ & $161.78^{\mathrm{e}}$ & $170.89^{\mathrm{cd}}$ & $175.00^{\mathrm{c}}$ & $163.19^{b}$ \\
\hline Mean & $188.25^{a}$ & $168.71^{b}$ & $152.88^{c}$ & $145.22^{\mathrm{c}}$ & $165.44^{\mathrm{b}}$ & $186.11^{a}$ & $183.00^{\mathrm{a}}$ & \\
\hline \multicolumn{9}{|c|}{ Leaf area $\left(\mathrm{cm}^{2}\right)$} \\
\hline & \multicolumn{8}{|c|}{2014} \\
\hline Cht & $33.27^{\mathrm{a}}$ & $29.69^{d}$ & $30.82^{\mathrm{c}}$ & $28.49^{\mathrm{d}}$ & $31.67^{\mathrm{bc}}$ & $32.14 \mathrm{a}^{\mathrm{b}}$ & $32.75^{\mathrm{a}}$ & $31.26^{\mathrm{a}}$ \\
\hline Put & $32.76^{\mathrm{b}}$ & $31.04^{\mathrm{c}}$ & $29.06^{\mathrm{e}}$ & $28.53^{\mathrm{d}}$ & $31.20^{\mathrm{c}}$ & $31.78 b^{c}$ & $32.31^{\mathrm{ab}}$ & $30.95^{b}$ \\
\hline \multirow[t]{2}{*}{ Mean } & $33.01^{\mathrm{a}}$ & $30.37^{\mathrm{b}}$ & $29.94^{b}$ & $28.51^{\mathrm{c}}$ & $31.43^{b}$ & $31.96^{\mathrm{b}}$ & $32.53^{\mathrm{a}}$ & \\
\hline & \multicolumn{8}{|c|}{2015} \\
\hline Cht & $32.54^{\mathrm{b}}$ & $31.21^{\mathrm{cd}}$ & $30.67^{\mathrm{e}}$ & $27.53^{\mathrm{e}}$ & $31.39^{\mathrm{d}}$ & $32.91^{\mathrm{c}}$ & $34.06^{\mathrm{b}}$ & $31.47^{a}$ \\
\hline Put & $33.40^{\mathrm{a}}$ & $31.59^{c}$ & $30.82^{\mathrm{de}}$ & $27.50^{\mathrm{e}}$ & $32.39^{c}$ & $33.03^{c}$ & $34.83^{\mathrm{a}}$ & $31.94^{a}$ \\
\hline Mean & $32.97^{\mathrm{a}}$ & $31.40^{b}$ & $30.75^{\mathrm{c}}$ & $27.52^{\mathrm{d}}$ & $31.89^{c}$ & $32.97^{\mathrm{b}}$ & $34.45^{\mathrm{a}}$ & \\
\hline
\end{tabular}

TABLE 3. Main and interaction effect of chitosan and putrescine foliar sprays and different irrigation Levels on leaf fresh and dry weight

\begin{tabular}{|c|c|c|c|c|c|c|c|c|}
\hline \multicolumn{9}{|c|}{ Leaf fresh weight (g) } \\
\hline \multirow{3}{*}{$\begin{array}{l}\text { Agrochemicals } \\
\text { (Agr.) }\end{array}$} & \multicolumn{3}{|c|}{ Irrigation intervals (A) } & \multicolumn{5}{|c|}{ Concentration $(\mathrm{C})$} \\
\hline & & & & $\mathbf{0}$ & 50 & 100 & 150 & Mean \\
\hline & $\mathbf{I}_{1}$ & $\mathbf{I}_{2}$ & $\mathbf{I}_{3}$ & ppm & ppm & ppm & ppm & \\
\hline & \multicolumn{8}{|c|}{2014} \\
\hline Cht & $0.661^{b}$ & $0.641^{\mathrm{b}}$ & $0.632^{b}$ & $0.625^{\mathrm{c}}$ & $0.631^{\mathrm{c}}$ & $0.646^{\mathrm{c}}$ & $0.677^{\mathrm{b}}$ & $0.645^{b}$ \\
\hline Put & $0.708^{\mathrm{a}}$ & $0.696^{\mathrm{a}}$ & $0.662^{b}$ & $0.631^{\mathrm{c}}$ & $0.678^{\mathrm{b}}$ & $0.726^{\mathrm{a}}$ & $0.720^{\mathrm{a}}$ & $0.689^{\mathrm{a}}$ \\
\hline \multirow{2}{*}{ Mean } & $0.684^{a}$ & $0.669^{\mathrm{ab}}$ & $0.647^{b}$ & $0.628^{c}$ & $0.654^{b}$ & $0.686^{a}$ & $0.699^{a}$ & \\
\hline & \multicolumn{8}{|c|}{2015} \\
\hline Cht & $0.688^{\mathrm{bc}}$ & $0.665^{\mathrm{de}}$ & $0.647^{\mathrm{e}}$ & $0.645^{\mathrm{e}}$ & $0.661^{\mathrm{de}}$ & $0.677^{\mathrm{c}}$ & $0.682^{b c}$ & $0.666^{b}$ \\
\hline Put & $0.714^{\mathrm{a}}$ & $0.697^{\mathrm{ab}}$ & $0.669^{\mathrm{cd}}$ & $0.649^{\mathrm{e}}$ & $0.682^{\mathrm{bc}}$ & $0.744^{\mathrm{a}}$ & $0.698^{\mathrm{b}}$ & $0.693^{\mathrm{a}}$ \\
\hline Mean & $0.701^{a}$ & $0.681^{b}$ & $0.658^{c}$ & $0.647^{d}$ & $0.672^{c}$ & $0.711^{\mathrm{a}}$ & $0.690^{b}$ & \\
\hline \multicolumn{9}{|c|}{ Leaf dry weight (g) } \\
\hline & \multicolumn{8}{|c|}{2014} \\
\hline Cht & $0.256^{\mathrm{a}}$ & $0.243^{b}$ & $0.231^{\mathrm{c}}$ & $0.221^{\mathrm{c}}$ & $0.240^{\mathrm{b}}$ & $0.256^{\mathrm{a}}$ & $0.256^{\mathrm{a}}$ & $0.243^{\mathrm{a}}$ \\
\hline Put & $0.255^{\mathrm{a}}$ & $0.241^{\mathrm{b}}$ & $0.230^{\mathrm{c}}$ & $0.223^{\mathrm{c}}$ & $0.240^{\mathrm{b}}$ & $0.250^{\mathrm{a}}$ & $0.255^{\mathrm{a}}$ & $0.242^{\mathrm{a}}$ \\
\hline \multirow[t]{2}{*}{ Mean } & $0.255^{\mathrm{a}}$ & $0.242^{b}$ & $0.230^{c}$ & $0.222^{c}$ & $0.240^{b}$ & $0.253^{a}$ & $0.255^{\mathrm{a}}$ & \\
\hline & \multicolumn{8}{|c|}{2015} \\
\hline Cht & $0.243^{b}$ & $0.236^{\mathrm{cd}}$ & $0.230^{\mathrm{de}}$ & $0.228^{\mathrm{f}}$ & $0.234^{\mathrm{d}}$ & $0.245^{b}$ & $0.238^{c}$ & $0.236^{b}$ \\
\hline \multirow[t]{2}{*}{ Put } & $0.259^{\mathrm{a}}$ & $0.237^{\mathrm{bc}}$ & $0.229^{\mathrm{e}}$ & $0.230^{\mathrm{ef}}$ & $0.233^{\mathrm{de}}$ & $0.266^{\mathrm{a}}$ & $0.238^{\mathrm{c}}$ & $0.242^{\mathrm{a}}$ \\
\hline & $0.251^{\mathrm{a}}$ & $0.236^{b}$ & $0.230^{c}$ & $0.229^{d}$ & $0.233^{c}$ & $0.255^{a}$ & $0.238^{b}$ & \\
\hline
\end{tabular}

Egypt. J. Hort. Vol. 45, No. 2 (2018) 
TABLE 4. Main and interaction effect of chitosan and putrescine foliar sprays and different irrigation Levels on RWC\% and total chlorophyll content

\begin{tabular}{|c|c|c|c|c|c|c|c|c|}
\hline \multicolumn{9}{|c|}{ RWC\% } \\
\hline \multirow{3}{*}{$\begin{array}{c}\text { Agrochemicals } \\
\text { (Agr.) }\end{array}$} & \multicolumn{3}{|c|}{ Irrigation intervals (A) } & \multicolumn{5}{|c|}{ Concentration (C) } \\
\hline & \multirow[b]{2}{*}{$\mathbf{I}_{1}$} & \multirow[b]{2}{*}{$\mathbf{I}_{2}$} & \multirow[b]{2}{*}{$\mathbf{I}_{3}$} & $\mathbf{0}$ & 50 & 100 & 150 & Mean \\
\hline & & & & ppm & & ppm & ppm & \\
\hline \multicolumn{9}{|c|}{2014} \\
\hline Cht & $60.07^{b}$ & $57.20^{\mathrm{c}}$ & $52.04^{\mathrm{e}}$ & $51.45^{\mathrm{e}}$ & $55.22^{\mathrm{d}}$ & $59.27^{b}$ & $59.81^{\mathrm{ab}}$ & $56.44 b$ \\
\hline Put & $62.87^{\mathrm{a}}$ & $55.70^{\mathrm{d}}$ & $53.15^{\mathrm{e}}$ & $51.48^{\mathrm{e}}$ & $57.35^{\mathrm{c}}$ & $60.16^{\mathrm{a}}$ & $59.96^{\mathrm{a}}$ & $57.24 a$ \\
\hline Mean & $61.47^{\mathrm{a}}$ & $56.45^{b}$ & $52.60^{c}$ & $51.47^{\mathfrak{c}}$ & $56.29^{\mathrm{b}}$ & $59.71^{\mathrm{a}}$ & $59.88^{\mathrm{a}}$ & \\
\hline \multicolumn{9}{|c|}{2015} \\
\hline Cht & $65.54 b$ & $61.82 \mathrm{c}$ & $56.29 \mathrm{e}$ & $54.82 \mathrm{f}$ & $59.46 \mathrm{e}$ & $64.37 \mathrm{c}$ & $66.20 \mathrm{a}$ & $61.21 b$ \\
\hline Put & $67.30 \mathrm{a}$ & $60.65 d$ & $56.43 \mathrm{e}$ & $54.85 f$ & $61.06 \mathrm{~d}$ & $65.44 b$ & $64.49 \mathrm{c}$ & $61.46 a$ \\
\hline Mean & $66.42^{a}$ & $61.23^{b}$ & $56.36^{c}$ & $54.83 d$ & $60.26^{c}$ & $64.91^{\mathrm{b}}$ & $65.34^{\mathrm{a}}$ & \\
\hline \multicolumn{9}{|c|}{ Leaf chlorophyll (SPAD unit) } \\
\hline \multicolumn{9}{|c|}{2014} \\
\hline Cht & $72.40^{\mathrm{a}}$ & $70.86^{\mathrm{b}}$ & $68.52^{\mathrm{c}}$ & $68.54^{\mathrm{c}}$ & $69.48^{\mathrm{c}}$ & $71.62^{\mathrm{b}}$ & $72.72^{\mathrm{a}}$ & 70.59a \\
\hline Put & $71.75^{\mathrm{ab}}$ & $70.70^{\mathrm{b}}$ & $68.47^{\mathrm{c}}$ & $68.54^{\mathrm{c}}$ & $69.49^{c}$ & $70.90^{\mathrm{b}}$ & $72.30^{\mathrm{a}}$ & $70.31 \mathrm{a}$ \\
\hline Mean & $72.08^{a}$ & $70.78^{a}$ & $68.49^{b}$ & $68.53^{c}$ & $69.49^{c}$ & $71.26^{\mathrm{b}}$ & $72.51^{\mathrm{a}}$ & \\
\hline \multicolumn{9}{|c|}{2015} \\
\hline Cht & $67.38^{\mathrm{a}}$ & $64.20^{\mathrm{b}}$ & $61.56^{\mathrm{c}}$ & $54.87^{d}$ & $65.07^{\mathrm{b}}$ & $68.76^{\mathrm{a}}$ & $68.31^{\mathrm{a}}$ & $64.38 \mathrm{a}$ \\
\hline Put & $64.27^{\mathrm{b}}$ & $61.06^{\mathrm{cd}}$ & $59.79^{d}$ & $55.38^{\mathrm{d}}$ & $62.21^{\mathrm{c}}$ & $63.49^{\mathrm{c}}$ & $65.76^{\mathrm{b}}$ & $61.71 b$ \\
\hline Mean & $65.83^{\mathrm{a}}$ & $62.63^{b}$ & $60.68^{c}$ & $55.13^{\mathrm{c}}$ & $63.64^{\mathrm{b}}$ & $66.38^{\mathrm{a}}$ & $67.03^{\mathrm{a}}$ & \\
\hline
\end{tabular}

of plant height growth in both years, followed by Put and irrigation every 7 days in both years and 14 day in 2014 , whereas the significant lowest percentages were brought by Cht and irrigation every 21 day in 2015 only. In reviewing the data of the percentages growth of stem diameter, it was noticed that no substantial variations among the different combinations of chit or Put under similar water deficit levels. However, the significant higher value was achieved by irrigation intervals 7 days with spraying Cht or Put in both seasons and 2015 only. It is clear that Put interacted with irrigation interval 7 days was recorded statistical higher values of number of leaves and leaf area in 2014 and 2015, respectively, and vice versa Cht and withholding irrigation 7 day attained higher leaves number and area in 2015 and 2014, respectively. It can be expected that there was negative relationship between number of leaves and leaf area. Likewise, the positive interaction of Cht spraying and withholding irrigation 14 and 21 day was emerged on the number of leaves and 21 day on leaf area in 2014. Leaf dry weight and RWC\% were more responsive to Put spraying with irrigation intervals 7 day in both years, as well as leaf fresh weight was substantially respond to Put spraying and irrigation every 7 and 14 day in both years and 21 day in 2015. Generally, Cht or Put was more interacted with irrigation every 7 and 14 day in relative to 21 day.

As for dual interactions of foliar spray applications and their doses used, as generally, it was found that the interactive effects of concentrations applied with Put were more positive on vegetative growth characteristics, in particular percentages of stem diameter growth, leaf area, leaf weights of fresh and dry and RWC\% as compared to Cht combinations at the same concentrations. While the number of leaves per seedlings was more affected by the combination of Cht, also no constant tendency was appeared between interactions of either Cht or Put and their concentrations used in percent of plant height growth. Overall, it was observed that Put at 50 or $100 \mathrm{ppm}$ was more influential on growth than 0 and $150 \mathrm{ppm}$, while, the impact of Cht was more pronounced at 100 and $150 \mathrm{ppm}$ than 0 and $50 \mathrm{ppm}$. The obtained results are in conformity with findings of many researchers who examined impact of drought stress on the vegetative growth characteristics, it has been induced through irrigation after depletion of different percentages of maximum total available soil water Farouk and Ramadan (2012) on cowpea, Abu-Muriefah (2013) on phaseolus vulgaris, Nohong and Nompo(2015) on grass, Malekpoor et al. (2016) on basil, Balal et al. (2017) on Cucumis sativus

Egypt. J. Hort. Vol. 45, No. 2 (2018) 
and (Bistgani et al., 2017) on Thymus daenensis or various irrigation intervals Hussein et al. (2013) on Jojoba, as well as salinity stress Ahmed et al. (2013) on cotton and boron or cadmium induced oxidative stress Balal, et al. (2017) on Cucumis sativus and Zong et al. (2017) on Brassicarapa, respectively. It was reported that vegetative growth criterions including plant height, number of leaves or branches per plant, fresh and dry weight of leaf, shoot or whole plant, as well as relative water content $\%$, all of them affected substantially by increasing drought stress, and the lowest values of the previous aspects were recorded under drought severely. The higher concentration of chitosan and putrescine indicated better influences on seedlings grown under low levels of irrigation. It is well known, $80 \%$ of plant tissue component is water, and thus water loss may have evident adverse effects and can be considered as the most important limiting factors for growth and development of plants. Zabihi et al. (2014) mentioned that during drought stress water potential surrounding the plant is lower than natural status and plant will encounter difficultly in water absorption. They added that as a result of insufficient water supply, plant growth is inhibited by the decrease in leaf extension level, rates of cell division and enlargement. Also, the uptake of essential elements and photosynthetic capacity under water deficiency are reduced that reflected indirectly the formation of vegetative shoots, leaves and fresh or dry weights accumulation Farouk \& Ramadan (2012), Nohong \& Nompo (2015) and Ahmed et al. (2017). Moreover, water stress have a negative effects on leaf RWC, where leaf RWC reflecting the metabolic activity in tissues that declined markedly due to water deficiency. Leaf RWC reduction could have been due to unavailability of water in the soil, root system that are not able to compensate for water lost by transpiration through a reduction of absorbing surface Bolat et al. (2014). Concerning the positive stimulating effects of chitosan foliar application on plant growth were discussed by El-Tanahy et al. (2012) and Farouk \& Ramadan (2012), who mentioned that chitosan may provide some amino compounds required for plant growth, that resulted in increasing total $\mathrm{N}$ content in leaves or higher ability of plants to absorb $\mathrm{N}$ from soil as chitosan might increase key enzymes activity of nitrogen metabolism and enhance transportation of nitrogen in the functional leaves Malekpooret al. (2016). Moreover, chitosan may be increase the availability, uptake and transport of essential nutrients via adjusting cell osmotic pressure and thereby progresses plant growth and development e.g. number of leaves or shoots, leaf area and total leaf area per plant that reversing in improving its fresh and dry weight.

Egypt. J. Hort. Vol. 45, No. 2 (2018)
Chitosan is reported to relieve drought stress and stimulate growth through diminishing the accumulation of harmful free radicals by activating antioxidants and enzymes Malekpoor et al. (2016). Also, chitosanin addressed to influence pathway involving jasmonic acid biosynthesis which plays a key role in the regulation of water use by plants Farouk and Ramadan (2012), Additionally, chitosan is stated to work as antitranspirant agent as it affects stomatal aperture Abu-Muriefah (2013).

Furthermore, putrescine is a polyamine that is involved in different plant growth and developmental processes. It simulated growth by increasing the amount of endogenous promoters such as auxin, gibberellins and cytokinins which accompanied with decreasing ABA inhibitors either content or activity Ahmed et al. (2013), Ahmed et al. (2017). In addition, polyamines can act as a source of nitrogen which stimulates growth, and also can bind to negatively charged molecules and stabilizes them Talaat and Gamal EL-Din (2005). Putrescine enhances plant tolerance to environmental stress by regulating stomatal closure and reducing water losing through transpiration which would all consequently reflect on amelioration of relative water content Gupta et al. (2012) and Ahmed \& Sadak, (2016).

\section{Biochemical characteristics \\ Leaf total chlorophyll}

Chitosan foliar spraying enhanced significantly chlorophyll content more than Put in 2015 only as is shown in Table 4. Thus, the changes in chlorophyll content during water shortages showed chlorophyll content of severewater stressed leaves (21d.) was significant lower than control- unstressed water (7d.) and moderate stress (14d) in both years, while it unchanged significantly in response to moderate stress relative to control. So, chlorophyll was more interacted with Cht spray and water deficit comparing to Put at the same water deficiency level. The trait increased gradually with raising concentration of foliar application i.e. using 150 or $100 \mathrm{ppm}$ recorded significant higher readings of total chlorophyll as compared to either 0ppm (control- water spray) or $50 \mathrm{ppm}$ that reflected on interactions between foliar application and its doses used, either Cht or Put at 150 and 100 ppm were more effective in enhancing chlorophyll content than each of them at 0 and $50 \mathrm{ppm}$. Photosynthetic pigments are important to plant mainly for harvesting light and production of reducing power, both of chlorophyll (a) and (b) are prone to soil drying that caused inhibition of chlorophyll synthesis Jaleel et al. (2009), Lisar et al. (2012). Results of the present study agreed with earlier findings of García-Sónchez et al. 
(2007), Ahmed et al. (2016) on citrus, Farouk and Ramadan (2012) on cowpea, Gupta et al. (2012), Karimi, (2016) on wheat and Chutia and Borah (2012) on rice. They all reported that chlorophyll content decreased to a significant level at higher water deficits, this reduction in chlorophyll under drought stress are mainly because the membrane disintegration and damage chloroplasts by overproduction of reactive oxygen species (ROS) or chlorophyll was decline through diminished biosynthetic pathway or oxidation during water stress Salekjalali et al. (2012). Also, they added Chitosan or putrescine foliar application at high concentration caused increment chlorophyll content in relative to control-water spray, beside the effect of either Cht or Put in counteracting water stress on this criterion decreased with raising water stress level. Cht might alleviate water stress via effect on photosynthetic pigments and increment chlorophyll content by enhancing endogenous level of cytokinins, which stimulate chlorophyll synthesis, it was referred these positive effects to greater availability of amino compound release from $\mathrm{Cht}$, moreover it was observed significant increase in both $\mathrm{N}$ and $\mathrm{K}$ content in plant shoots sprayed with Cht, that may be play an important role in increasing number of chloroplasts per cell, cell size and number per unit area, as well as increased synthesis of chlorophyll according to Farouk and Ramadan, (2012),
Ahmed et al. (2016). On the opposite side, Gupta et al. (2012) who was reported that a significant reduction in membrane injury after Put spraying, protect the membranes and other macromolecules from oxidative damages and stabilized biological membranes under stressful conditions which in trun delayed chlorophyll degradation.

\section{Leaf total carbohydrates content}

Data in Table 5 represented total carbohydrates, Cht foliar spray induced significant increases in carbohydrates as compared to Put in first year only. Leaf carbohydrates accumulation reduced statistically with prolonged irrigation shortages, therefore the least values appeared in irrigation withholding for 21day, whereas the highest one was detected in irrigation every 7 day and the moderate intervals recorded intermediated values between them. It was obvious that foliar spraying combined with control-normal irrigation (7day) were more influential in accumulating carbohydrates in leaves in comparison with put treatment under the same drought stress level in both years and 14 day in 2014 day. While, put spraying at irrigation intervals 21 day were superior significantly over Cht spraying at the same intervals, the observation hold valid in 2015

Aside from drought stress and foliar applications in both years, concentrations were

TABLE 5. Main and interaction effect of chitosan and putrescine foliar sprays and different irrigationLevels on total carbohydrates and phenols \%

\begin{tabular}{|c|c|c|c|c|c|c|c|c|}
\hline \multicolumn{9}{|c|}{ Carbohydrates (\%) } \\
\hline \multirow{3}{*}{$\begin{array}{c}\text { Agrochemicals } \\
\text { (Agr.) }\end{array}$} & \multicolumn{3}{|c|}{ Irrigation intervals (A) } & \multicolumn{5}{|c|}{ Concentration (C) } \\
\hline & \multirow[b]{2}{*}{$\mathbf{I}_{1}$} & \multirow[b]{2}{*}{$\mathbf{I}_{2}$} & \multirow[b]{2}{*}{$\mathbf{I}_{3}$} & \multirow{2}{*}{$\begin{array}{c}\text { 0 } \\
\text { ppm }\end{array}$} & \multirow{2}{*}{$\begin{array}{c}50 \\
\text { ppm }\end{array}$} & \multirow{2}{*}{$\begin{array}{c}100 \\
\text { ppm }\end{array}$} & \multirow{2}{*}{$\begin{array}{l}150 \\
\text { ppm }\end{array}$} & \multirow[t]{2}{*}{ Mean } \\
\hline & & & & & & & & \\
\hline \multicolumn{9}{|c|}{2014} \\
\hline Cht & $59.24^{\mathrm{a}}$ & $53.50^{\mathrm{b}}$ & $49.37^{\mathrm{c}}$ & $49.46^{\mathrm{d}}$ & $52.4^{\text {bc }}$ & $57.68^{\mathrm{a}}$ & $56.54^{\mathrm{a}}$ & $54.04^{a}$ \\
\hline Put & $55.47^{\mathrm{b}}$ & $50.69^{c}$ & $49.48^{\mathrm{c}}$ & $50.04^{\mathrm{d}}$ & $50.94^{\mathrm{cd}}$ & $52.25^{\mathrm{bc}}$ & $53.68^{\mathrm{b}}$ & $51.88^{b}$ \\
\hline Mean & $57.36^{\mathrm{a}}$ & $52.09^{b}$ & $49.43^{c}$ & $49.75^{c}$ & $51.70^{b}$ & $55.27^{\mathrm{a}}$ & $55.11^{\mathrm{a}}$ & \\
\hline \multicolumn{9}{|c|}{2015} \\
\hline Cht & $48.34^{\mathrm{a}}$ & $44.15^{\mathrm{bc}}$ & $35.56^{\mathrm{e}}$ & $38.71^{\mathrm{d}}$ & $40.81^{\mathrm{c}}$ & $45.47^{\mathrm{a}}$ & $45.73^{\mathrm{a}}$ & $42.68^{a}$ \\
\hline Put & $44.93^{b}$ & $42.60^{c}$ & $38.04^{\mathrm{d}}$ & $38.40^{\mathrm{d}}$ & $40.10^{\text {cd }}$ & $43.52^{\mathrm{b}}$ & $45.41^{\mathrm{ab}}$ & $41.86^{a}$ \\
\hline Mean & $46.63^{\mathrm{a}}$ & $43.37^{b}$ & $36.80^{c}$ & $38.56^{c}$ & $40.46^{b}$ & $44.50^{\mathrm{a}}$ & $45.57^{\mathrm{a}}$ & \\
\hline \multicolumn{9}{|c|}{ Phenols (\%) } \\
\hline \multicolumn{9}{|c|}{2014} \\
\hline Cht & $0.394^{\mathrm{c}}$ & $0.448^{b}$ & $0.494^{\mathrm{a}}$ & $0.398^{c}$ & $0.436^{\mathrm{b}}$ & $0.469^{\mathrm{a}}$ & $0.479^{\mathrm{a}}$ & $0.445^{\mathrm{a}}$ \\
\hline Put & $0.384^{\mathrm{c}}$ & $0.433^{\mathrm{b}}$ & $0.481^{\mathrm{a}}$ & $0.392^{\mathrm{c}}$ & $0.433^{\mathrm{b}}$ & $0.442^{\mathrm{b}}$ & $0.463^{\mathrm{a}}$ & $0.433^{b}$ \\
\hline Mean & $0.389^{c}$ & $0.441^{b}$ & $0.488^{a}$ & $0.395^{\mathrm{d}}$ & $0.435^{c}$ & $0.456^{b}$ & $0.471^{a}$ & \\
\hline \multicolumn{9}{|c|}{2015} \\
\hline Cht & $0.422^{\mathrm{d}}$ & $0.476^{\mathrm{bc}}$ & $0.532^{\mathrm{a}}$ & $0.417^{\mathrm{d}}$ & $0.461^{\mathrm{cd}}$ & $0.494^{\mathrm{bc}}$ & $0.535^{\mathrm{ab}}$ & $0.477^{a}$ \\
\hline Put & $0.448^{\mathrm{cd}}$ & $0.501^{\mathrm{ab}}$ & $0.497^{\mathrm{ab}}$ & $0.433^{\mathrm{d}}$ & $0.455^{\mathrm{cd}}$ & $0.493 b c$ & $0.548^{\mathrm{a}}$ & $0.482^{a}$ \\
\hline Mean & $0.435^{b}$ & $0.489^{\mathrm{a}}$ & $0.515^{\mathrm{a}}$ & $0.425^{\mathrm{c}}$ & $0.458^{\mathrm{c}}$ & $0.493^{b}$ & $0.542^{\mathrm{a}}$ & \\
\hline
\end{tabular}


applied at 150 and $100 \mathrm{ppm}$ attained significant higher values of carbohydrates \% comparatively to 0 and $50 \mathrm{ppm}$. The pattern of increases in the combination between foliar treatments and its doses almost followed the effect of concentrations alone, either Cht or Put spraying at 150 and $100 \mathrm{ppm}$ brought significant improvement as compared to Cht or put at 50 or 0 control-water spray, beside it was observed that Cht at 100 and $150 \mathrm{ppm}$ induced carbohydrates accumulation more than put at $100 \mathrm{ppm}$ in both years and 150 ppm in 2015 only. In the light of many studied reported that total soluble sugars concentration increased markedly upon raising a biotic stress level either drought or salinity that plant exposed to it, the mechanism of plant to relieved the negative effects of drought stress is by regulating osmotic potential of the cell, especially if drought stress increased from mild or severe stress. Osmotic cell potential can be adjusted by increasing total soluble sugars which can decrease water potential of cell without inhibiting the function of enzymes and does not reduce turgid of cell, also sugars accumulation helps to maintain the stability of the membrane through prevent and protect membrane fusion Gupta et al. (2012),Ahmed et al. (2013), Sinay and Karuwal (2014), Nohong and Nompo (2015),Lisaret al. (2012).On the other hand, the present results in this connection revealed that carbohydrates accumulation was decreased parallel with level of water deficit, likely due to plant under drought stress was tended to retain soluble sugars rather than converting to carbohydrates probably attributed to its mentioned above role in osmotic adjustment. Beside, the reduction of potassium under stress condition of drought or salinity Ahmed et al. (2013), Ahmed et al.(2017), Lisar et al.(2012) that resulted carbohydrates metabolism process reduced based on potassium is essential translocation of sugars and formation starch and carbohydrates, as well as it helps to regulate the production of high energy compound needed to drive metabolic processes Mohamed and Tanany (2016), so it has been suggested that stressful plant is unable to provide energy needed to convert sugars to carbohydrates. Lastly, our findings agreed with EL-Tanahy et al. (2012), Ahmed et al. (2016), they indicated that total carbohydrates was more reacted to $\mathrm{Cht}$ spraying at high concentration in comparison with low dose or control- water spray, also Cht effects to improve carbohydrates decreased with increasing irrigation shortages Farouk and Ramadan (2012).

\section{Leaf phenolic compounds}

The statistical analysis of phenols data in Table 5 indicate that seedlings treated by $\mathrm{Cht}$ had a significant higher content of phenols comparatively to Put during 2014, although Put treatments recorded higher value in 2015 the significant difference was disappeared. Water deficiency intensity was influenced significantly leaf phenolics content i.e. droughted seedling for 21 day was more productive of phenols than other that irrigated either every 14 day during 2014 or 7 days in both years. Increases of phenolic contents were in an ascending order with elevating the concentrations applied regardless of foliar applications or drought stress level. Otherwise, the singly behavior of drought stress, foliar applications or doses used was reversed on their dual interactions, therefore, seedling exposed to severe drought stress and treated with either Chit or Put achieved a significant higher phenols than the similar treatments under unstressed or moderate stress conditions in both years and in 2014 only, respectively. The significant differences were more consistent resulted from Put spraying at 150 ppm compared to Chit and Put at 0 or $50 \mathrm{ppm}$ and Put at $100 \mathrm{ppm}$. The values of phenols in 2015 was higher than 2014 may due plant became large and phenolic concentrations accumulated constantly as stress level intensified Bistgani et al.(2017). However, these results are matching with Ahmed et al(2013), Ahmed et al.(2016), Ahmed et al. (2017), Edziri et al.(2017) and Pirbalouti et al.(2017), who reported that drought or salinity stress conditions affected positively phenolics content, in general, they demonstrated that the production of phenols in plant tissues raises under abiotic stress,, as well as phenolics compound induced to accumulate in response to Cht or Put foliar spray compared to control water spray Bolat et al. (2014). In the most frequently, it was detected a significant combination between exogenous $\mathrm{Cht}$ or Put application with different levels of drought stress or doses applied, particularly severe stress and the highest concentration in comparing to untreated and normal irrigation. It is well known phenols are naturally occurring substances in plant and its production was increased as a plant reaction to drought stress which induced a defense response and increase secondary metabolite levels and the antioxidant activity of phenolics compound is mainly caused by redox properties that permit them to act as reducing agent, hydrogen donors and quenching the energy of ROS according to Pirbalouti et al. (2017), they added elicitation is a method that stimulates plant to build up secondary metabolites, it has been reported many elicitors interacted with plant membrane receptors and create signal compounds that induce expression of genes encoding enzymes of secondary metabolites biosynthesis and also can have an indirect effect on phenolics accumulation in plants. Likewise, Cht is referred to as familiar elicitor to sign specific molecules that could act as a stress messenger to induce 
suitable reaction to stressful conditions Bistgani et al. (2017). Furthermore, application of Cht to soybean leaf tissues have been reported to cause an increase activity of phenylalanine ammonia lyase (PAL) and tyrosine ammonia lyase (TAL), the key enzymes of phenylpropanoid pathway. The products of PAL and TAL are modulated via phenylpropanoid metabolism to precursors of secondary metabolites containing flavonoid pigments and phytoalexins Ahmedet al. (2016). Moreover, our results regarding Put treatments were in line with Mandal et al. (2013), they documented that total phenolics and flavonoids content increased in Salvinia natans plant under exogenous application of Put $(1 \mathrm{mM})$ and $100 \mu \mathrm{M}$ $\mathrm{H}_{2} \mathrm{O}_{2}$ as an indirect stressor for establishment of oxidative damage compared with the highest dose of $\mathrm{H}_{2} \mathrm{O}_{2}(100 \mu \mathrm{M})$ only without Put treatment. This increase may be ascribe to polyamine has been in regulation $\mathrm{H}_{2} \mathrm{O}_{2}$ generation plants, since $\mathrm{H}_{2} \mathrm{O}_{2}$ is generally one of decomposition products from Put oxidation by di-amine oxidase catalyzed by $\mathrm{Cu} \mathrm{Ao}$ during stress conditions Zabihi et al. (2014), Li et al.(2015) which in turn activation of phenolic synthesis as potential agents in scavenging activity of ROS.

\section{Leaf protein content $\%$}

Concerning leaf protein content (\%), data in Table 6 showed no striking changes affected by foliar treatments, except chit spraying attained significant lower than Put treatment in 2015 only. Also, there was a significant decrease with prolonged irrigation intervals, the highest content obtained from normal irrigation (7day), whereas severe level (21 day) produced the lowest protein content and the moderate level (14day) recorded intermediate values between them. In contrast, the significant increase in protein was brought with elevating the doses used. There is no pronounced effect of interactions between foliar application with either water stress or concentration used i.e. a significant difference was detected between put and Cht applications during irrigation withholding (21day),as well as put at 100 and $150 \mathrm{ppm}$ was more influential on protein than chit at the same concentration in 2015 only. Drought conditions bring about quantitative and qualitative adjustments in plant proteins, in popular, leaf protein content decrease all through water deficiency via damage reasons to protein synthesize that resulted from increasing activity of protease which cause proteolysis, and also decrease synthesis through substrate material for protein synthesis were not supplied, consequently rate of process greatly decreased or even stopped Mohammadkhani \& Heidari (2007), Chutia \& Borah (2012), Salekjalali \& Jafari (2012), Kala \&Godara(2011) and Lisar et al. (2017). Furthermore, the highest values of protein were recorded by using $\mathrm{Cht}$ at high concentration relative to lower one or control- water spray El-Tanahy et al. (2012) and Farouk \&Ramadan (2012). Nevertheless, there was a clear superiority of put treatments in leaf protein accumulation more than Cht, may have been the cause put is a diamine involved in important biological processes such as ionic balance and DNA, RNA and protein stabilization Ahmed et al. (2013)

TABLE 6. Main and interaction effect of chitosan and putrescine foliar sprays and different irrigation Levels onleaf protein $\%$ and proline content

\begin{tabular}{|c|c|c|c|c|c|c|c|c|}
\hline \multicolumn{9}{|c|}{ protein \% } \\
\hline \multirow{3}{*}{$\begin{array}{l}\text { Agrochemicals } \\
\text { (Agr.) }\end{array}$} & \multicolumn{3}{|c|}{ Irrigation intervals (A) } & \multicolumn{5}{|c|}{ Concentration (C) } \\
\hline & & & & $\mathbf{0}$ & 50 & 100 & 150 & Mean \\
\hline & $\mathbf{I}_{1}$ & $\mathbf{I}_{2}$ & $\mathbf{I}_{3}$ & ppm & ppm & ppm & ppm & \\
\hline \multicolumn{9}{|c|}{2014} \\
\hline Cht & $2.43^{\mathrm{a}}$ & $2.14^{\mathrm{b}}$ & $1.94^{\mathrm{c}}$ & $1.98^{\mathrm{ef}}$ & $2.04^{\mathrm{de}}$ & $2.18^{\mathrm{c}}$ & $2.46^{\mathrm{a}}$ & $2.17^{\mathrm{a}}$ \\
\hline Put & $2.37^{\mathrm{a}}$ & $2.15^{\mathrm{b}}$ & $2.02^{\mathrm{bc}}$ & $1.96^{\mathrm{f}}$ & $2.09^{d}$ & $2.26^{\mathrm{b}}$ & $2.40^{\mathrm{a}}$ & $2.18^{\mathrm{a}}$ \\
\hline \multicolumn{9}{|c|}{2015} \\
\hline Cht & $1.68^{a}$ & $1.52^{\mathrm{bc}}$ & $1.35^{\mathrm{d}}$ & $1.34^{\mathrm{d}}$ & $1.44^{\mathrm{c}}$ & $1.57^{\mathrm{b}}$ & $1.70^{\mathrm{a}}$ & $1.52^{b}$ \\
\hline Put & $1.72^{\mathrm{a}}$ & $1.59^{\mathrm{b}}$ & $1.49^{\mathrm{c}}$ & $1.33^{\mathrm{d}}$ & $1.63^{\mathrm{b}}$ & $1.71^{\mathrm{a}}$ & $1.74^{\mathrm{a}}$ & $1.60^{\mathrm{a}}$ \\
\hline Mean & $1.70^{\mathrm{a}}$ & $1.55^{b}$ & $1.42^{\mathrm{c}}$ & $1.33^{d}$ & $1.54^{\mathrm{c}}$ & $1.64^{b}$ & $1.72^{\mathrm{a}}$ & \\
\hline \multicolumn{9}{|c|}{ proline $\mathrm{mg} \mathrm{g}^{-1} \mathrm{DW}$} \\
\hline \multicolumn{9}{|c|}{2015} \\
\hline Cht & $0.408^{\mathrm{b}}$ & $0.405^{\mathrm{b}}$ & $0.547^{\mathrm{a}}$ & $0.400^{\mathrm{c}}$ & $0.413^{\mathrm{c}}$ & $0.533^{a}$ & $0.469^{b}$ & $0.454^{\mathrm{a}}$ \\
\hline Put & $0.324^{\mathrm{c}}$ & $0.388^{b}$ & $0.547^{\mathrm{a}}$ & $0.400^{\mathrm{c}}$ & $0.421^{\mathrm{c}}$ & $0.403^{\mathrm{c}}$ & $0.454^{b}$ & $0.420^{b}$ \\
\hline Mean & $0.366^{b}$ & $0.397^{b}$ & $0.547^{\mathrm{a}}$ & $0.400^{b}$ & $0.417^{b}$ & $0.468^{a}$ & $0.461^{\mathrm{a}}$ & \\
\hline
\end{tabular}




\section{Leaf proline content}

Regarding to proline content, data in Table 6 \& Fig. 1 revealed that leaf proline content varied statistically in response to singly effects of foliar applications, there was a significant superiority for Cht spraying in increasing leaf proline content as compared to Put in both seasons. As for effects of drought stress, the highest amount of proline was obtained by withholding irrigation 21 day followed by 14 day then 7 day, the result hold valid during second year without significant variation between two latter irrigation intervals. Also, the combination of irrigation intervals and foliar treatments followed the trend of proline under water stress levels, thus either Cht or Put under severe stress recorded highest proline content and the lowest values were observed in both foliar application and irrigation intervals 7 day, no detectable variations between the different combinations except Cht was more effective in enhancing leaf proline content than Put under moderate stress or normal irrigation in 2014 and 2015 , respectively. Concentration of 100 ppm was topped significantly in proline accumulation in both seasons, as well as 50 and $150 \mathrm{ppm}$ in 2014 and 2015, respectively. While, interaction between Cht spraying at $100 \mathrm{ppm}$ had synergic effect on leaf proline amount in both years followed by Put spraying at 50 ppm in 2014 and both of Cht and Put at $150 \mathrm{ppm}$ in 2015.These results supported by other reports published earlier, it was decided that drought stress by using either watering intervals or different percentages of pot and field capacity, had a significant effect on leaf or shoot proline content Lakmini et al. (2006), Kala and Godara (2011), Chutia and Borah (2012), Jabasingh and Babu (2013), Bolat et al. (2014), Sinay and Karuwal(2014), Nohong and Nompo (2015). It was evident, as the present results indicated, that proline content increase with prolonged stress duration that might be due to the activities of enzymes involved in proline accumulation in plant subjected to drought stress were enhanced significantly in the leaves with decreasing leaf water potential, while the activities of proline dehydrogenase, which is the first enzyme in catabolic pathway of proline considerably decreased with decreasing leaf water potential according to Chaitanya et al. (2009). Furthermore, plant have ability to protect cells damage resulted from low its water potential, through accumulate non- toxic compounds such as proline performs an adaptive role as osmotic adjustment that the main approach of plant to avoid unfavorable consequences Nohong and Nompo (2016), as well as, the plant ability of countering adverse effects of water deficiency was improve via proline contributes to stabilizing sub-cellular structures e.g. membranes and proteins, scavenging free radicals and alleviating cytoplasmic acidosis and maintaining NADP/NADPH ratios compatible with metabolism Karimi (2016). Nevertheless, our findings are in the most frequently matched with Gupta et al. (2012), Ahmed et al. (2013), Karimi (2016) and Ahmed et al. (2017), they investigated Put foliar spray at one or various concentrations under drought or salinity stress. It was observed the higher concentration was concomitant with reducing proline content as compared to lower one, beside the ability of put to enhance proline was realized with increasing stress intensity. In addition, the results agreed with Öztürk \& Demir (2003), Khorshidi \& Hamedi (2014) and Barzegar et al. (2016), who illustrated that different levels of salinity or drought stress interacted positively with Put application and inducing proline amount in comparison with non- Put treatment either under normal or stressed conditions It should also be noted that Put catabolism via diamine oxidase that could contribute to proline accumulation Ahmed et al. (2013), therefore the negative effect of increasing Put concentration used on the proline content possibly due to exogenous application of Put caused down- regulation of endogenous Put biosynthesis Liu et al. (2017) and ultimately resulted in reducing proline accumulation based on there was a negative correlation between proline accumulation and endogenous Put content Su and Bai (2008), moreover Aziz et al. (1998), they emphasized that Put exogenously supplied at low concentrations stimulated the proline response which was suppressed by application of spermine. Interestingly, it was occurred positively inversion in proline content as response to combination of Put spraying and $150 \mathrm{ppm}$ that recorded markedly the highest concentration of proline compared to Put spray at 0 or $50 \mathrm{ppm}$. The present findings regarding Cht were in harmony to great extent with those of Boonlertnirun et al. (2013), Ganzález et al. (2015), they studied leaf proline content as affected by Chtat various doses under drought and salinity stress or the method of application. The best trend having high content of rice seedling with foliar applied Cht and concentration at $100 \mathrm{mgL}^{-1}$ increased markedly proline content in relative to control-water spray and the highest dose of Cht $\left(500 \mathrm{mgL}^{-1}\right)$. In contrast, our results were disagreed with Zong et al. (2017) they reported that Cht under cd-stress did not differ over Cht alone and control-cd free. Additionally, they explained foliar Cht spray might contribute to proline synthesis for sustaining water potential in plant resulted in reduction of drought injury.

\section{Catalase and Peroxidase activity}

In general, water stress was induced formation ROS and oxidative damages as mentioned before, therefore it was essential to investigate peroxidase 


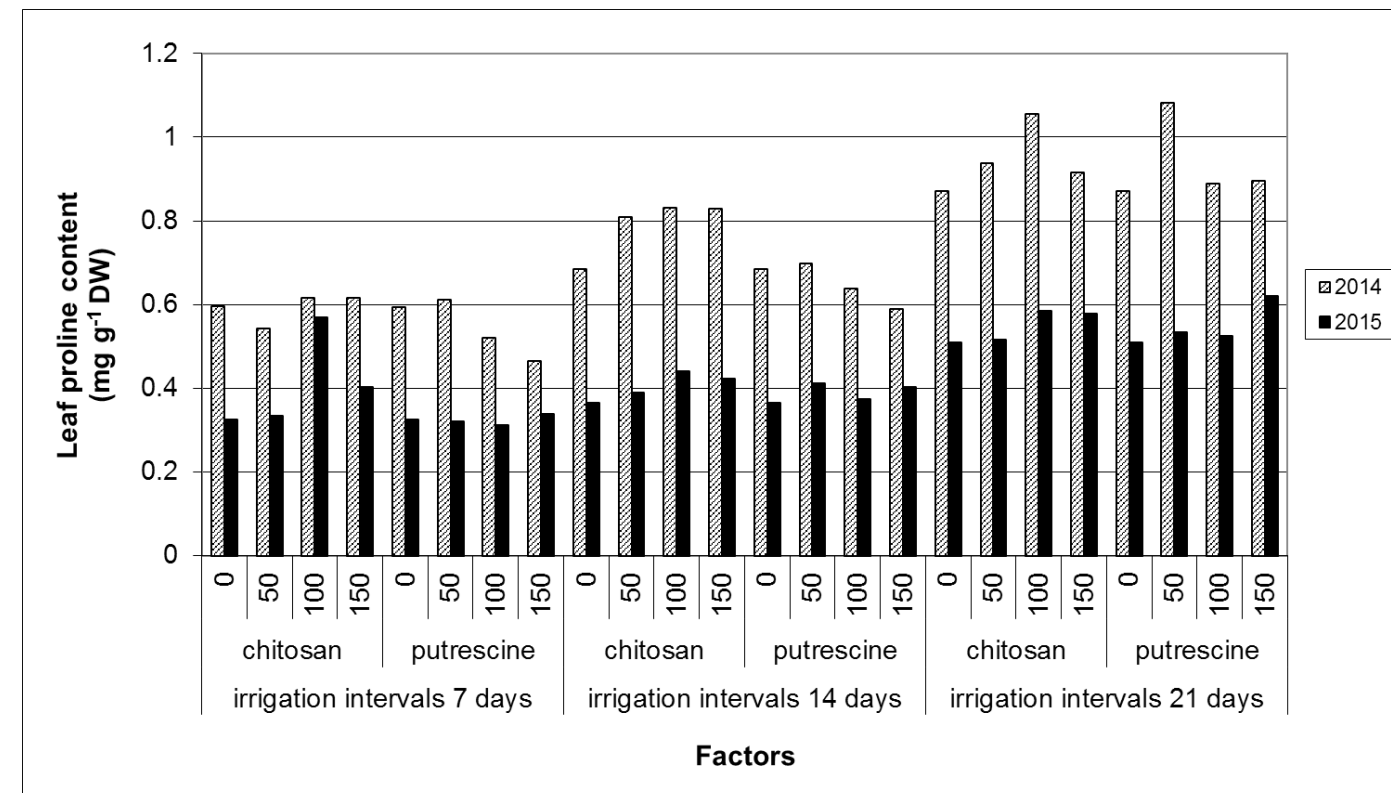

Fig. 1. Effect of foliar chitosan or putrescine at different levels of doses and irrigation Intervals on leaf proline content

and catalase activities as an oxidant components responsible for ROS scavenging. The results in Table 7 \& Fig.2 (a\&b) demonstrated that the enzymes activity was altered significantly to foliar applications, It seemed that CAT was more responsive to Cht than Put foliar application, whereas Put recorded higher values of POX activity than Cht, as well as POX and CAT activities increased gradually with increasing water shortage to 14 and 21 day as compared to control-7 day. Also, the raising of concentrations used was accompanied with a significant activation of CAT and POX enzymes in both years. The obtained data showed that foliar Cht or Put spraying interacted significantly with increasing irrigation intervals, therefore, seedling sprayed with Cht and Put and irrigated every 21 day recorded the highest activity of both studied enzymes followed by 14 days compared to 7 days. Moreover, leaf CAT and POX activities were affected markedly by positive interaction of Cht or Put foliar spray and its increasing doses, so the maximum values of both enzymes was appeared at 150 and 100 ppm as compared to 0 and $50 \mathrm{ppm}$. These results are in confirmation with Cunhua et al. (2010), Salekjalali et al. (2012), Movludi et al. (2014), Barzegar et al. (2016), Ahmed et al. (2017), Liu et al. (2017) and Zong et al. (2017). They all showed that water deficit induced strongly CAT and POX activities and the higher induction was observed under water shortage in severely than moderately, so the highest amount of both enzymes was obtained in severe stress than those under controlwell watered conditions, as well as there was a liner and significant increase CAT activity in response to water stress Mohammadkhani and Heidari (2007).

It could be considered as response to drought induced oxidative damage, thus CAT and POX play a crucial role as a defensive strategies in protective plants against free oxygen radical on the membrane lipids, causing detoxification and decomposition directly hydrogen peroxide produced by the cells to $\mathrm{H}_{2} \mathrm{O}+\mathrm{O}$, beside $\mathrm{POX}$ is among the main enzymes that scavenges $\mathrm{H}_{2} \mathrm{O}_{2}$ in chloroplasts which dismutation of $\mathrm{O}_{2}{ }_{2}$ catalyzed by Superoxide Dismutase activity (SOD) and thereby it suppress the breakdown of plant protein Movludi et al. (2014), Zong et al. (2017). On contrary, our findings were disagree with Dacosta and Huang (2007), Mandal et al. (2013), Bolat et al. (2014), González et al. (2015),Ahmed et al. (2017), Balal et al. (2017), who found leaf CAT activity did not change significantly under drought stress, whereas salinity stress statistically decreased activities of CAT and POX and $\mathrm{H}_{2} \mathrm{O}_{2}$ stress caused reduction in CAT activity comparatively to control, however it was reported that not all oxidant enzymes changes in their activities at the same time or with the same pattern in response to stress.

From our findings, it can be inferred that both moderate and severe drought stress had higher activities of CAT and POX, which implied that the increase pattern in protective enzymes was probably induced gradually by expression of certain protective genes in early stages of drought stress until reach the peak in severe stress which 
were strengthened to defend the attacks of ROS to membrane lipids and protect structure and function of cellular membrane system, this might be part of self- protection mechanisms in plants Cunhua et al. (2010).Further the current results are coincide with Balal et al. (2017), they stated that Cht were highly significant on POX and CAT activity under all boron stress levels, particularly higher level of both boron stress and doses of Cht was sprayed compared to non- Cht spray or lower dose, meanwhile Jabeen and Ahmed (2013), they suggested that the reduction of CAT and POX activities as resulted of low concentrations of chitosan under salinity stress might be caused by the superoxide scavenging ability provided by its low doses because antioxidants play an important role in preventing stress-induced accumulation of toxic concentrations of ROS, therefore the antioxidant properties of chitosan could also enhance resistance to oxidative stress in plants.

In addition, our findings are in accordance with Zong et al. (2017), they displayed that exogenous application of Cht with low molecular weight $(1 \mathrm{Kd})$ induced markedly the activity of CAT in leaves exposed to cadmium (cd) treatment as a

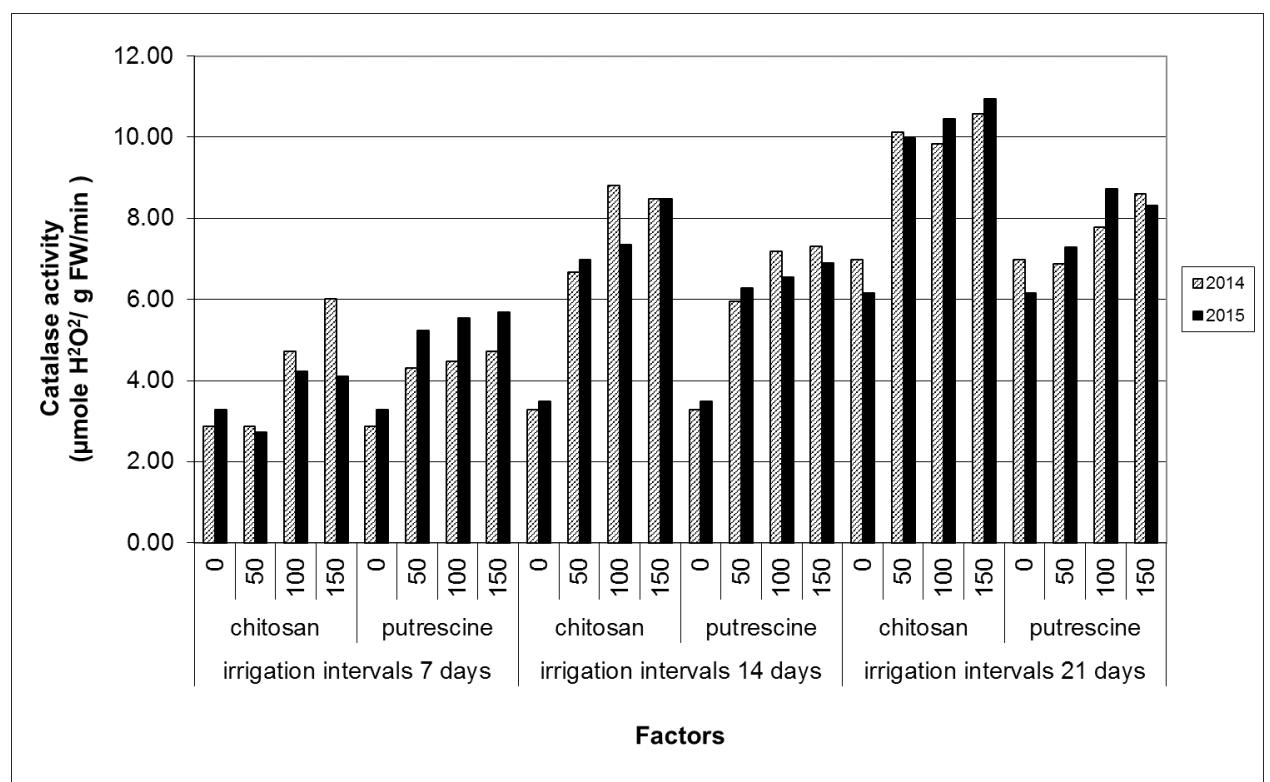

Fig. 2(a). Effect of foliar chitosan or putrescine at different levels of doses and irrigation intervals on leaf CAT activitiy

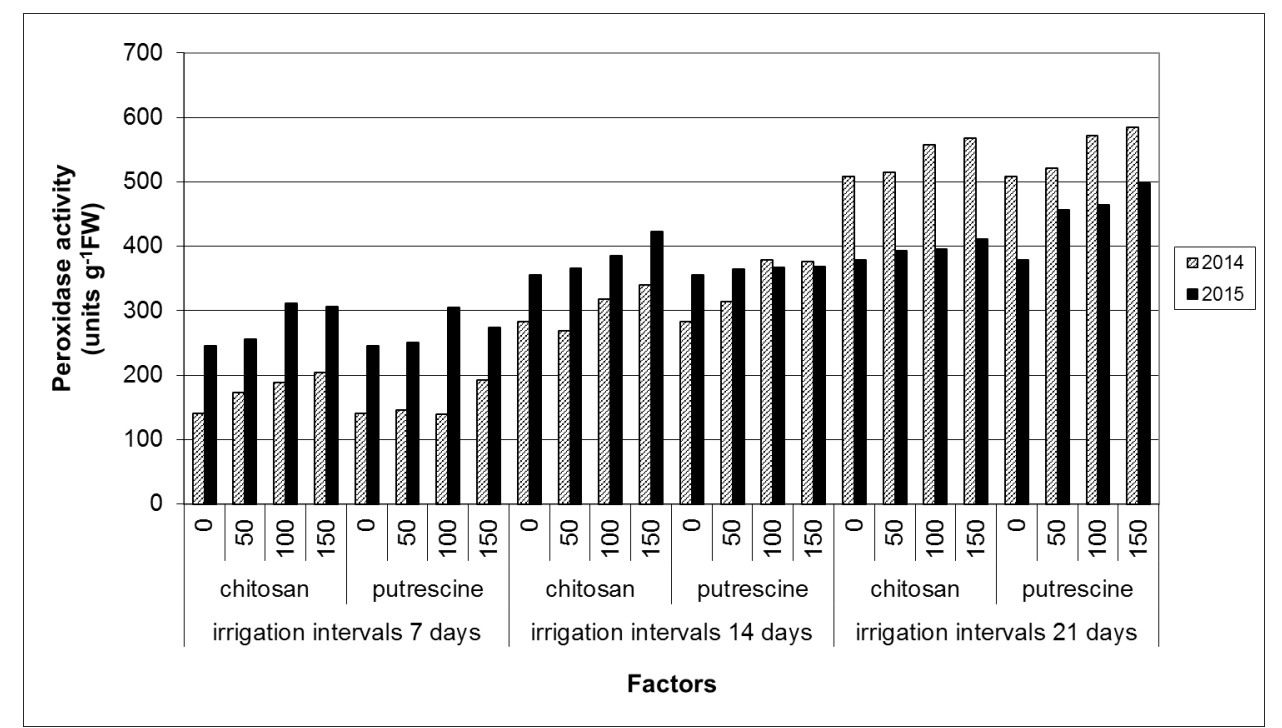

Fig. 2(b). Effect of foliar chitosan or putrescine at different levels of doses and irrigation intervals on leaf POX activity .

Egypt. J. Hort. Vol. 45, No. 2 (2018) 
TABLE 7. Main and interaction effect of chitosan and putrescine foliar sprays and different irrigation levels on leaf catalase and peroxidase activity

\begin{tabular}{|c|c|c|c|c|c|c|c|c|}
\hline \multicolumn{9}{|c|}{ Catalase activity $\left(\mu\right.$ mole $\left.\mathrm{H}_{2} \mathrm{O}_{2} / \mathrm{g} \mathrm{FW} / \mathrm{min}\right)$} \\
\hline Agrochemicals & \multicolumn{3}{|c|}{ Trrigation intervals $(\mathrm{A})$} & \multicolumn{5}{|c|}{ Concentration (C) } \\
\hline \multirow{2}{*}{ (Agr.) } & $I_{1}$ & $I_{2}$ & $I_{3}$ & $\mathbf{0}$ & 50 & 100 & 150 & Mean \\
\hline & & & & ppm & ppm & ppm & ppm & \\
\hline \multicolumn{9}{|c|}{2014} \\
\hline Cht & $4.12^{\mathrm{e}}$ & $6.84^{\mathrm{c}}$ & $9.38^{\mathrm{a}}$ & $4.37^{\mathrm{c}}$ & $6.58 \mathrm{c}^{\mathrm{d}}$ & $7.79^{\mathrm{b}}$ & $8.36^{\mathrm{a}}$ & $6.78^{\mathrm{a}}$ \\
\hline Put & $4.09^{\mathrm{e}}$ & $5.93^{\mathrm{d}}$ & $7.56^{\mathrm{b}}$ & $4.25^{\mathrm{f}}$ & $5.71^{\mathrm{e}}$ & $6.48^{\mathrm{d}}$ & $7.01^{\mathrm{c}}$ & $5.86^{\mathrm{b}}$ \\
\hline Mean & $4.11^{\mathrm{c}}$ & $6.38^{b}$ & $8.47^{\mathrm{a}}$ & $4.31^{\mathrm{d}}$ & $6.15^{\mathrm{c}}$ & $7.13^{b}$ & $7.69^{\mathrm{a}}$ & \\
\hline \multicolumn{9}{|c|}{2015} \\
\hline Cht & $3.58^{\mathrm{f}}$ & $6.57^{\mathrm{c}}$ & $9.58^{\mathrm{a}}$ & $4.21^{\mathrm{e}}$ & $6.56^{\mathrm{d}}$ & $7.44^{\mathrm{b}}$ & $7.85^{\mathrm{a}}$ & $6.51^{\mathrm{a}}$ \\
\hline Put & $4.93^{\mathrm{e}}$ & $5.80^{\mathrm{d}}$ & $7.62^{\mathrm{b}}$ & $4.31^{\mathrm{e}}$ & $6.27^{\mathrm{d}}$ & $6.94^{\mathrm{c}}$ & $6.96^{\mathrm{c}}$ & $6.12^{b}$ \\
\hline Mean & $4.26^{\mathrm{c}}$ & $6.19^{b}$ & $8.60^{\mathrm{a}}$ & $4.26^{d}$ & $6.42^{\mathrm{c}}$ & $7.19^{\mathrm{b}}$ & $7.41^{\mathrm{a}}$ & \\
\hline \multicolumn{9}{|c|}{ Peroxidase activity (units $\mathrm{g}^{-1} \mathrm{FW}$ ) } \\
\hline \multicolumn{9}{|c|}{2014} \\
\hline Cht & $176.65^{\mathrm{e}}$ & $302.35^{\mathrm{d}}$ & $537.02^{\mathrm{b}}$ & $310.39^{\mathrm{g}}$ & $318.74^{\mathrm{f}}$ & $354.69^{d}$ & $370.89^{b}$ & $338.68^{b}$ \\
\hline Put & $154.88^{\mathrm{f}}$ & $337.88^{c}$ & $546.47^{\mathrm{a}}$ & $310.39^{\mathrm{g}}$ & $327.15^{\mathrm{e}}$ & $363.26^{\mathrm{c}}$ & $384.82^{\mathrm{a}}$ & $346.40^{\mathrm{a}}$ \\
\hline Mean & $165.77^{\mathrm{c}}$ & $320.11^{b}$ & $541.75^{\mathrm{a}}$ & $310.39^{d}$ & $322.94^{c}$ & $358.98^{b}$ & $377.86^{a}$ & \\
\hline \multicolumn{9}{|c|}{2015} \\
\hline Cht & $279.63^{\mathrm{e}}$ & $382.11^{\mathrm{c}}$ & $394.55^{\mathrm{b}}$ & $326.35^{\mathrm{e}}$ & $338.20^{\mathrm{d}}$ & $364.29^{b}$ & $379.53^{\mathrm{a}}$ & $352.09^{b}$ \\
\hline Put & $268.97^{\mathrm{f}}$ & $364.23^{\mathrm{d}}$ & $449.08^{\mathrm{a}}$ & $326.35^{\mathrm{e}}$ & $357.56^{\mathrm{c}}$ & $378.96^{\mathrm{a}}$ & $380.15^{\mathrm{a}}$ & $360.75^{a}$ \\
\hline Mean & $274.30^{\mathrm{c}}$ & $373.17^{b}$ & $421.81^{a}$ & $326.35^{d}$ & $347.89^{c}$ & $371.63^{b}$ & $379.84^{a}$ & \\
\hline
\end{tabular}

heavy metal stress in comparing to control- cd free or cd- stressed plant without Cht treatment, as well as Cht spraying only. Likewise, the present results are partially in line with González et al. (2015), they showed that under normal conditions or salinity stress, POX and CAT was stimulated after Cht treatment at the higher dose $\left(500 \mathrm{mgL}^{-1}\right)$, beside $\left(100 \mathrm{ml} \mathrm{L}^{-1}\right)$ under stress only as compared to control- untreated, perhaps higher concentration could put the cell on the alert strengthening defenses. Meanwhile these concentrations repressed the enzymes activity under stress of salinity in comparison with normal condition. The results regarding Put were supported by many earlier publishers, where they studied the impact of Put treatment on CAT or POX activity under exposure to several of a biotic stress at different levels, such as drought, salinity and $\mathrm{H}_{2} \mathrm{O}_{2}$ that is considered an indirect stressor for establishment of oxidative damage. They found Put treatment lead to activate CAT under stress, particularly at higher stress level comparing to stress - untreated Öztürk and Demir (2003), Mandal et al. (2013). Also it was observed, Put affected significantly leaf CAT activity depend on its concentration, the maximum values of enzyme activity achieved at higher dose of Put, whereas the results regarding
Peroxidase disagreed with the present findings, where it was reported peroxidase activity was significantly reduced by Put foliar application Barzegar et al. (2016).Furthermore it has been decided that although the molecular mechanism of polyamines is still not understood improved tolerance to drought stress, polyamines could be catalyzed by polyamine oxidase (PAO) that was promoted by stress Aziz et al. (1998) to produced $\mathrm{H}_{2} \mathrm{O}_{2}$ in apoplast .The accumulation $\mathrm{H}_{2} \mathrm{O}_{2}$ as a result of polyamine oxidation lead to induce expression of antioxidant enzyme encoding genes in tobacco plant Liu et al. (2017), therefore antioxidant system(CAT, SOD, APX,GR) might be regulated by polyamines, this was confirmed by our results, CAT and POX activity, were activated significantly with elevating Put dose, also they added, exogenous of polyamines increased substantially abundance of several other stress- related protein.

\section{Conclusion}

In general, it might be concluded that foliar sprays of chitosan and putrescine would have positive impact on enhancing the growth of Sour orange seedlings under low irrigation levels by 
the use of concentration ranging from 100 to 150 ppm as foliar spray application.

Acknowledgments: First and foremost, I would like to express my sincere gratitude to Dr. Ahmed Rafik Elmahdy Professor of Food Science and Technology Dept., Faculty of Agriculture, Alexandria University, Egypt, for his guidance helped me in all chemical analysis schemes of research, his continuous support and revision of this manuscript. My deep appreciation goes out to Dr. Ahmed Amer EL-Settawy Professor and Head of Forestry and Wood Technology Dept., Faculty of Agriculture, Alexandria University, Egypt, for giving the opportunity to carry out the current work in his laboratory, and providing all the facilities is available to achieve this research.

Funding statements: The authors declare that there is no received external funding for this study.

Conflicts of interest: The authors declare that the research was conducted in the absence of any commercial or financial relationships that could be construed as a potential conflict of interest.

\section{References}

Abu-Muriefah, S.S. (2013) Effect of chitosan on common bean (Phaseolus vulgaris L.) plants grown under water stress conditions. Int. Res. Journal of Agric. Sci. Soil Sci., 3 (6) 192-199.

Ahmed, H.H.A., Aboul-Ella Nesiem, M.R., Allam, H.A. and El-Wakil, A.F.(2016) Effect of preharvest chitosan foliar application on growth, yield and chemical composition of Washington navel orange trees grown in two different regions. Afr. $J$. Biochem. Res., 10 (7), pp. 59-69.

Ahmed, A.H.H, Darwish, E. and Alobaidy, M.G. (2017) Impact of putrescine and 24-epibrassinolide on growth, yield and chemical constituents of cotton (Gossypium barbadense L.) plant grown under drought stress conditions. Asian J. Plant Sci., 16(1), 9-23.

Ahmed, A.H.H., Darwish, E., Hamoda, S.A.F. and Alobaidy, M.G. (2013) Effect of putrescine and humic acid on growth, yield and chemical composition of cotton plants grown under saline soil conditions. Am-Euras. J. Agric. Environ. Sci., 13 (4), 479-497.

Ahmed, M.MR. M. and Sadak, M.Sh. (2016) Effect of putrescine foliar application on Wheat genotypes (Triticumaestivum L.) under water stress conditions. Int. J. PharmTech Res., 9 (8), 94-102.

Anon (2015) Central Agency for Public Mobilization and Statistics (CAPMAS), Annual bulletin of irrigation and water resources statistics.

Egypt. J. Hort. Vol. 45, No. 2 (2018)
Aziz, A., Martin-Tanguy, J. and Larher, F. (1998) Stress-induced changes in polyamine and tyramine levels can regulate proline accumulation in tomato leaf discs treated with sodium chloride.Physiol. Plant, 104, 195- 202.

Balal, R.M., Shahid, M.A., Javaid, M.M., Iqbal, Z., Liu, G.D., Zotarelli, L. and Khan, N. (2017) Chitosan alleviates phytotoxicity caused by boron through augmented polyamine metabolism and antioxidant activities and reduce boron concentration in Cucumis sativus L. Acta Physiol. Plant, 39, 31,15 p.

Barzegar, T., Moradi, P., Nikbakht, J. and Ghahremani1, Z. (2016) Physiological response okra cv. Kano to foliar to application of putrescine and humic acid under water deficit stress. Int. J. Hort. Sci. Technol, 3 (2) 187- 197.

Basu, S., Ramegowda, V., Kumar, A. and Pereira, A. (2016) Plant adaptation to drought stress. F1000Research, 5(F1000 Faculty Rev):1554 Last updated: 30JUN

Bates, L.S.,Walderm, R.P. and Teare, I.D. (1973) Rapid determination of free proline for water stress studies. Plant and Soil, 39, 205- 207.

Bistgani, Z. E., Siadat, S. A., Bakhshandeh, A.,Pirbalouti,A. G. andHashemi, M. (2017) Morpho-physiological and phytochemical traits of (Thymus daenensisCelak.) in response to deficit irrigation and chitosan application Acta Physiol Plant, 39, 231,13 p.

Bolat, I., Dikilitas, M., Ercisli, S., Ikinci, A. and Tonkaz, T. (2014) The effect of water stress on some morphological, physiological, and biochemical characteristics and bud success on apple and quince rootstocks. Sci. World J., Vol. 2014, 8 p.

Boonlertnirun, S., Suvannasara, R. and Boonlertnirun, K. (2013) Effects of chitosan application before being subjected to drought on physiological changes and yield potential of rice (Oryza sativa L.). J. Appl. Sci. Res., 9 (12), pp. 6140- 6145.

Bradford, M.M. (1976) A rapid and sensitive method for quantitation of microgram quantities of protein utilizing the principle of protein-dye binding.Anal. Biochem., 72, 248- 254.

Castle, W. S. (1995) Rootstock as a fruit quality factor in citrus and deciduous tree crops. N. Z. J. Crop Hortic. Sci., 23 (4), 383-394.

Castle, W. S., Pelosi, R.R., Youtsey, C.O., Gmitter, F.G., JR., Lee, R.F Powell, C.A. and Hu, X. (1992) Rootstocks similar to sour orange for florid citrus trees. Proc. Fla. State Hort. Soc., 105, 56-60. 
Chaitanya, K.V., Rasineni, G.K. and Reddy, A.R. (2009) Biochemical responses to drought stress in mulberry (Morusalba L.): evaluation of proline, glycine betaine and abscisic acid accumulation in five cultivars. Acta Physiol Plant, 31 (3), 437-443.

Cheung., R.C.F., Ng, T.B., Wong, J.H. and Chan, W.Y.(2015) Chitosan: An Update on Potential Biomedical and Pharmaceutical Applications. Mar. Drugs, 13 (8), 5156-5186.

Chutia, J. and Borah, S. P. (2012) Water stress effects on leaf growth and chlorophyll content but not the grain yield in traditional rice (Oryza sativa Linn.) genotypes ofassam, India II. Protein and proline status in seedlings under PEG induced water stress. Amer. J. Plant Sci., 3 (7), 971- 980.

Cunhua, S., Wei, D., Xiangling, C., Xinna, X., Yahong, Z., Dong, S. and Jianjie, S. (2010) The effects of drought stress on the activity of acid phosphatase and its protective enzymes in pigweed leave. Afr. $J$. Biotechnol., 9 (6), 825-833.

Cimen, B. and Yesiloglu, T. (2016) Rootstock breeding for abiotic stress tolerance in citrus. In: Shanker AK, Shanker C (Ed.), Abiotic and biotic stress in plants - Recent Advances and Future Perspectives, Dr. Arun Shanker (Ed.) In Tech 527-563.

DaCosta, M. and Huang, B. (2007) Changes in antioxidant enzyme activities and lipid peroxidation for bentgrass species in response to drought stress. J. Amer. Sci., 132 (3), 319-326.

Dzung, N.A., Khanh, V.T.P. and Dzung, T.T. (2011) Research on impact of chitosan oligomers on biophysical characteristics, growth, development and drought resistance of coffee. Carbohydr. Polym., 84, 751-755.

Edziri, H., Mastouri, Cheheb, H., Laameri, S., Boujnah, D. (2017) The effect of water stress on leaf phenolic composition, Fluorescence parameters, xylem hydraulic properties and antiradical activity of four Tunisian olive (Oleaeuropaea L.) cultivars. J. Plant Biochem. Physiol., 5 (3), 6 p.

El-Tanahy, A.M.M., Mahmoud, A.R., Abde-Mouty, M. M. and Ali, A. H. (2012) Effect of chitosan doses and nitrogen sources on the growth, yield and seed quality of cowpea.Aus. J. Basic. Appl. Sci., 6 (4), 115-121.

Farouk, S.and Ramadan, A. (2012) Improving growth and yield of cowpea by foliar application of chitosan under water stress. Egypt. J. Biology, 14, 14- 26.
García-Sáncheza, F., Syvertsena, J.P., Gimeno, V., Botía, P. and Perez-Perez, J.G. (2007) Responses to flooding and drought stress by two citrus rootstock seedlings with different water-use efficiency. Physiol. Plant, 130 (4) 532-542.

González, L.M., Guerrero, Y. R., Rodríguez, A. F. and Vázquez, M.N. (2015) Effect of seed treatment with chitosan on the growth of rice (OryzasativaL.) seedling cv. INCA LP-5 IN salin medium. Cultivos Tropicales, 36 (1),136-142.

Gupta, S., Agarwal, V.P. and Gupta, N.K. (2012) Efficacy of putrescine and benzyladenine on photosynthesis and productivity in relation to drought tolerance in wheat (Triticum aestivum L.) Physiol. Mol. Biol. Plants., 18, 331-336.

Hussein, M. M, Tawfik, M. M., Ahmed, M. K. A and El Karamany, M. F. (2013) Effect of water stress on vegetative growth and some physiological aspects of Jojoba [Simmondsia chinensis (Link) Schneider] in newly reclaimed sandy soil. Elixir Pollution, 55, 12903-12909.

Jabasingh, C. and Babu, S.S. (2013) Prolinecontent of Oryza sativa L. under water stress. J. Academia and Indus. Res. (JAIR) 2, (7), 442- 445.

Jabeen, N. and Ahmad, R. (2013) The activity of antioxidant enzymes in response to salt stress in safflower (Carthamus tinctorius L.) and sunflower (Helianthus annuus L.) seedlings raised from seed treated with chitosan. J. Sci. Food Agric., 93 (7), $1699-1705$.

Jaleel, C.A.,Manivannan, P.,Wahid, A.,Farooq, M., AL-Juburi, H.J., Somasundaram, R. and Vam, R.P. (2009) Drought stress in plants: A review on morphological characteristics and pigments composition. Int. J. Agric. Biol., 11 (1),100-105.

Kala, S. and Godara, A.K. (2011) Effect of moisture stress on leaf total proteins, proline and free amino acid content in commercial cultivars of Ziziphus mauritiana. J. Sci. Res., 55, 65-69.

Kara, M. and Mishra (1976) Catalase, Peroxidase and polyphenoloxidase activities during rice leaf senescence.Plant Physiol., 57 (2), 315-319.

Karimi, Z. (2016) Putrescine foliar application effect on physiologic and morphologic characteristics of wheat (Tiriticum aestivumvar sw-82-9) under water deficit Stress.Biological Forum - An International Journal, 8 (1), 532-539. 
Katiyar, D., Hemantaranjan, A. and Singh, B. (2015) Chitosan as a promising natural compound to enhance potential physiological responses in plant: a review. Ind. J. Plant Physiol., 20 (1), 1-9.

Khan, N. and Naqvi, F.N. (2010) Effect of water on lipid peroxidation and antioxidant enzymes in local bread wheat hexaploids. J. Food Agric. Environ., 8 (2), 521-526.

Khorshidi, M. and Hamedi, F. (2014) Effect of putrescine on lemon balm under salt stress. Intl J Agri. Crop Sci., 7 (9), 601-609.

Lakmini, W.G.D., Nainanayake, N.P.A.D. and De Costa, W.A.J.M. (2006) Biochemical changes of four different coconut (Cocos nusifera L.) forms under moisture stress conditions. J. Agric. Sci., 2 (3),1-7.

Levy, Y. (1998) Citrus irrigation. p. 113-126. In: M. El-Otmani and A. Ait-Oubahou (eds.), Nouveaux acquis de la recherche en agrumiculture. Inst. AgronomiqueVeterinaire Hassan II, Agadir, Morocco

Li, Z., Zhang, Y., Peng, D., Wang, X., Peng, Y., He, X., Zhang, X., Ma, X., Huang, L. and Yanhong, Y. (2015) Polyamine regulates tolerance to water stress in leaves of white clover associated with antioxidants defense and hydringenes via involvement in calcium messenger system and hydrogen peroxide signaling. Front Physiol, 280 (6), $16 \mathrm{p}$.

Lisar, S.Y.S., Motafakkerazad, R., Hossain MM and Rahman IMM, 2012. Water Stress in Plants: Causes, effects and responses. InTech. pp.1-14.

Liu, M., Chen, J., Guo, Z. and Lu, S. (2017) Differential Responses of Polyamines and antioxidants to drought in a centipede grass Mutant in comparison to Its wild Type Plants. Front. Plant Sci., 792 (8), $11 \mathrm{p}$.

Malekpoor, F., Pirbalout, A. G. and Salim, A. (2016) Effect of foliar application of chitosan on morphological and physiological characteristics of basil under reduced irrigation. Res. Crops, 17 (2), 354-359.

Mandal, C., Ghosh, N., Adak, M. K. and Dey, N. (2013) Interaction of polyamine on oxidative stress induced by exogenously applied hydrogen peroxide in Salvinia natans Linn. Theoretical and Experimental Plant Physiology, 25 (3), 203-212.

Mohamed, S. A. and El-Tanany, M. M. (2016) Efficacy of foliar applications of salicylic acid, zinc and potassium on reducing fruit drop, yield improvement and quality of Balady mandarins. Egypt. J. Hort., 43 (20), 371- 388.

Egypt. J. Hort. Vol. 45, No. 2 (2018)
Mohammadkhani, N. and Heidari, R. (2007) Effect of drought stress on protective enzyme activities and lipid peroxidation in two maize cultivars. Pak.J. Biol.Sci., 10 (21), 3835-3840.

Movludi, A., Ebadi, A., Jahanbakhsh, S., Davari, M. and Parmoon, G. (2014) The effect of water deficit and nitrogen on the antioxidant enzymes' activity and quantum yield of barley (Hordeumvulgare L.). Not. Bot. Horti. Agrobo., 42 (2), 398- 404.

Nohong, B. and Nompo, S. (2015) Effect of water stress on growth, yield, proline and soluble sugars contents of Signal grass and Napier grass species. Am-Euras J. Sustainable Agric. 9 (5), 14-21.

Öztürk1, L. and Demir, Y. (2003) Effects of putrescine and ethephon on some oxidative stress enzyme activities and proline content in salt stressed spinach leaves. Plant Growth Regulation 40, 89-95.

Pirbalouti1, A. G, Malekpoor, F., Salimi, A., Golparvar, A. and Hamedi, B. (2017) Effects of foliar of the application chitosan and reduced irrigation on essential oil yield, total phenol content and antioxidant activity of extracts from green and purple basil. Acta Sci. Pol. Hortorum Cultus, 16 (6), 177-186.

Radwan, M.S. (1973) Leaf area estimation in berseem clover.Yugoslavian J. For Agric. XXI (1), 53-56.

Robles, J.M., Botía, P. and Pérez-Pérez, J.G. (2017) Sour orange rootstock increases water productivity in deficit irrigated 'Verna' lemon trees compared with Citrus macrophylla. Agric Water Manag, 186, 98-107.

Salekjalali, M., Haddad, R. and Jafari, B. (2012) Effect of water shortages on the activity of antioxidant enzymes and contents of chlorophyll and proteins in barley. Am-Euras. J. Agric. Environ. Sci., 12 (1),57-63.

Shehata, S. A., Zakaria, F. F. and El-Ramady, H.R. (2012) Response of cucumber plants to foliar application of chitosan and yeast under greenhouse conditions. Aust. J. Basicand Appli. Sci., 6 (4), 6371.

Sinay, H. and Karuwa, R. L. (2014) Proline and total soluble sugar content at the vegetative phase of six corn cultivars from Kisar Island Maluku, grown under drought stress conditions. Int. J. Adv. Agric. Res., 2, 77-82.

Steel, R.C.D. and Torrie, J.H. (1980) Principles and Procedures of Statistics, $2^{\text {nd }}$ ed., McGraw-Hill, Book Co., Inc., New York, U. S.A. 633 p. 
Su, G.X. and Bai, X. (2008) Contribution of putrescine degradation to proline accumulation in soybean leaves under salinity. Biol Plantarum, 52 (4), 796799.

Talaat, I.M. and Gamal El-Din, K.M. (2005) Physiological effect of putrescine and heat hardening on Nigella sativa L. Plants. Int.J. Agri. Biol., 7 (3), 358-362.

Weurman, C. and T. Swain (1995) Changes in the enzymicbrowning of Bramley's seedling apples during their development. J. Sci. Food Agric., 6,186-192.

Woodman, A.G. (1941) Food Analysis, Mc Grow Hill Book Company, Inc. New Yourk.

Yadava, U.L. (1986) A rapid and nondestructive method to determine chlorophyll in intact leaves. Hort. Sci., 21, 1449-1450.
Zabihi, A., Satei, A. and Ghorbanli, M. (2014). Evaluation effect of putrescine treatment on growth factors of soybean (Glycine max L.) under drought stress induced by polyethylene glycol.J. Appl. Environ. Biol. Sci., 4 (4) 24-32.

Zong, H., Liu, S., Xing, R., Chen, X. and Li, P. (2017) Protective effect of chitosan on photosynthesis and antioxidative defense system in edible rape (Brassicarapa L.) in the presence of cadmium. Ecotoxicol. Environ. Saf., 138, 271278.

(Received 21/04/2018; accepted 10/07/2018)

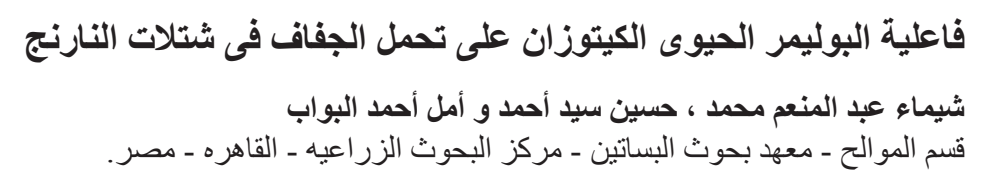

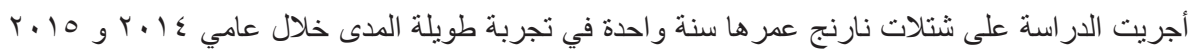

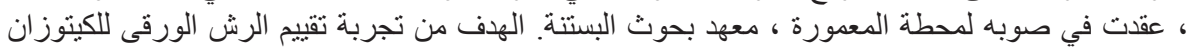

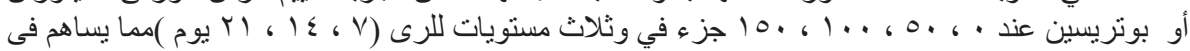

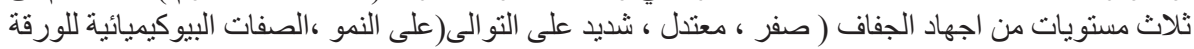

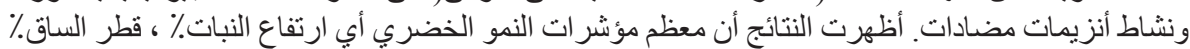

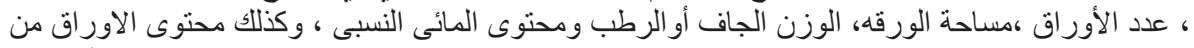

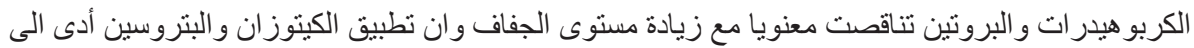

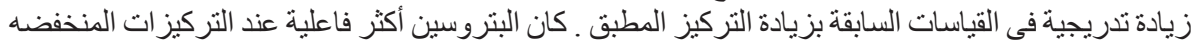

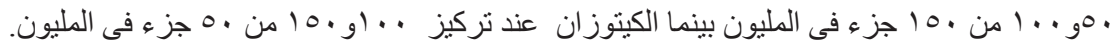

Egypt. J. Hort. Vol. 45, No. 2 (2018) 